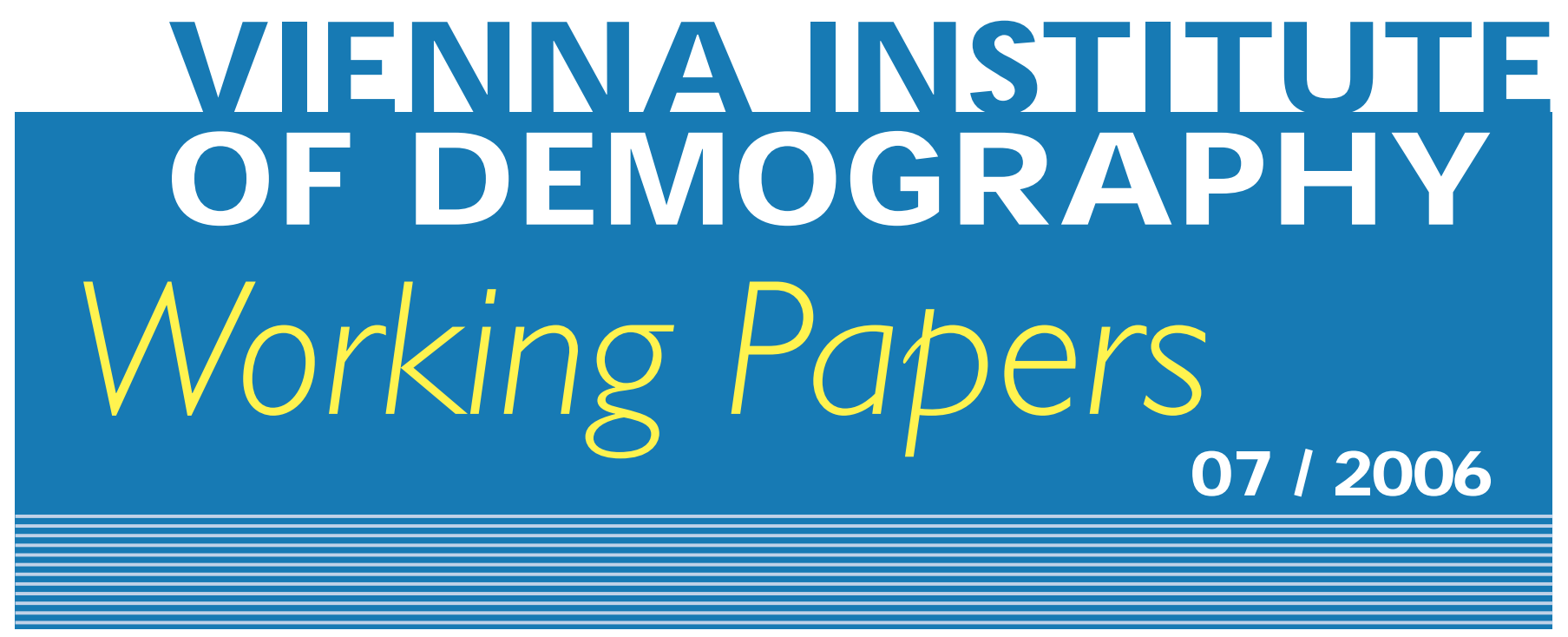

Anne Goujon and Samir K.C.

\title{
Past and Future of H uman Capital in Southeast Asia: From 1970 to 2030
}

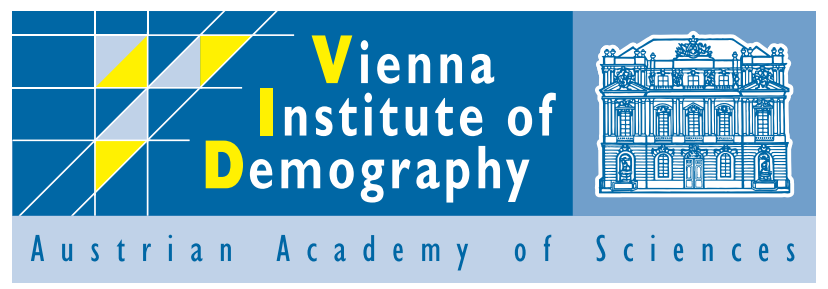

Vienna Institute of Demography

A ustrian A cademy of Sciences

Prinz Eugen-Straße 8-10 · A-1040 Vienna · A ustria

E-Mail: vid@ oeaw.ac.at

W ebsite: www.oeaw.ac.at/vid 


\begin{abstract}
This paper examines levels of educational attainment in Indonesia, Malaysia, Philippines, Singapore, Thailand, and Vietnam for the period 1970-2030 through the reconstruction and projection of levels of educational attainment. While the study of the past shows that the determination to invest in education has been strong in the six countries, the investments were implemented at different pace and intensity, the projections show the legacy of past investments. In Singapore, Malaysia, and Thailand, there will be tangible increases in the proportion of the working age population with a tertiary education. The Philippines will have a dichotomous society where large proportions will either have a tertiary education or only a primary education. In Indonesia, the bulk of the working age population will shift from primary in 2000 to secondary by 2030 . The projection horizon and the trend type of scenario do not allow Vietnam to catch up with the other countries.
\end{abstract}

\title{
Keywords
}

Southeast Asia, education, human capital.

\section{Authors}

Anne Goujon is a research scientist at the Vienna Institute of Demography, Austrian Academy of Sciences and part-timer researcher in the World Population Program at the International Institute for Applied Systems Analysis (Tel. +43 1515817719 Fax. +43 1515811130 Anne.Goujon@oeaw.ac.at).

Samir K.C. is a researcher in the World Population Program at the International Institute for Applied Systems Analysis (Tel. +43 2236807424 Fax. +43223671313 kc@iiasa.ac.at).

\section{Acknowledgments}

The starting point of this work was accomplished in the framework of a training workshop held between October 6th and October 17th, 2003 on "Past and Future Demographic Trends by Level of Education in the Countries of South-East Asia" at the College of Population Studies. We would like to acknowledge the work accomplished by many students whose input was greatly valuable to the present work: Wien Kusdiatmono, Endang Ediastuti, and Dewi Prihastuti (for the Indonesia Team); Wan Roslida Othman and Rafliza Ramli (for the Malaysia Team); Socorro Abejo, Lilia V. Elloso, Marymell Martillan, and Nimfa B. Ogena (for the Philippines Team); Santosh Jatrana and Yap Mui Teng (for the Singapore Team); Supaporn Arunraksombat, Preeya Mithranon, and Chanphen Tanasuppakomkul (for the Thailand Team); Dinh Thai Son and Pham Thi Thu Phuong (for the Vietnam Team). 


\title{
Past and Future of Human Capital in Southeast Asia: From 1970 to 2030
}

\author{
Anne Goujon and Samir K.C.
}

\section{Introduction}

This paper concerns himself with looking at the past and the future of human capital as measured by levels of educational attainment in six countries of the Southeast Asian region: Indonesia, Malaysia, Philippines, Singapore, Thailand, and Vietnam. This is obtained by implementing population backward and forward projections by levels of educational attainment.

In Southeast Asia, governments have taken very seriously the message that education is likely to play an increasing role for their economies, as can be seen from the development plans of the countries belonging to the region. The example of high performing Asian economies Japan, Hong Kong, Korea, Taipei China, including also Indonesia, Malaysia, Singapore, and Thailand shows that the maintenance of a strong human resource base is critical for good economic performance, with a strong emphasis in the first stage on primary education; and on vocational and technical education at the secondary level in a first stage and then more diversified in a second stage. The first of the four principles of the Thai national plan for the period 2007-2011 is to develop people into quality citizens with both virtue and knowledge ${ }^{1}$. An important focus of Indonesia's medium term development plan (2004-2009) is to improve the rate of economic growth through among others "improving human resources ... to better prepare persons for the labour market and for greater participation in the economy" (Bappenas, 2006). Similar objectives are found in medium term development plan for the Philippines (2004-2010). The Socio-economic development strategy of Vietnam (2001-2010) is also targeted at raising the quality, renewing the structure and expanding the scope of education and training system ${ }^{2}$. In Singapore, education is at the heart of the planning as the mission of the education service "is to mould the future of the nation, by moulding the people who will determine the future of the nation"3. Strengthening human capital is seen as a challenge in the ninth Malaysia Plan (2006-2010) to move away from the notion that Malaysia is a nation with 'first class infrastructure, but third class mentality'

Hence, enhancing education development is not only seen as a mean to meet people's basic rights to education but also to equip the countries to meet the future challenges for economic development. Before the economic crisis at the end of the 1990s, education was said to be one, if not the main, factor allowing the region to have such a high economic growth, particularly

\footnotetext{
${ }^{1}$ Source: Government of Thailand public relations department at http://thailand.prd.go.th/ [Consulted on 16/10/2006]

${ }^{2}$ Source: Ministry of Planning and Investment at http://www.mpi.gov.vn/strategy.aspx [Consulted on 16/10/2006]

${ }^{3}$ Source: Ministry of education at http://www.moe.gov.sg/corporate/mission_statement.htm

4 Source: http://www.epu.jpm.my/rm9/html/english.htm
} 
in the case of four fast growing economies: Indonesia, Malaysia, Singapore and Thailand. After the crisis, it seems that most governments plan to use human capital to regain high economic growth and to extend it further. The region has certainly an advantage as more than two thirds of all children in the Philippines, Malaysia, Thailand, and Vietnam attend secondary school. Trends in demography are also playing in favour of those countries, as the school-age population is already diminishing in Indonesia, Thailand, and Vietnam, and will do so by 2010 in Malaysia and the Philippines. However, whereas exports of labor-intensive and low skilled products was the key to the economic advantage of Southeast Asia, it may be of lesser importance as more countries within East- and South-Asia follow the same recipe, having to compete with the two giant neighbouring economies that are India, and China. The increased competition in low skilled industries pushed the Southeast Asian economies to increase their ability to "the ability to absorb and master new technologies and on the skill of the labour force. Both of these factors are partly dependent on education." (Sjöholm, 2002).

The paper will summarize in a first part the main stage of human capital development in the six countries. After a short look at the methodology for back- and forward projecting educational attainment, the article will present the main features of the past and future of human capital in each country from 1970 up to 2030.

\section{Education: Past Main Developments}

Indonesia, Malaysia, Singapore, and Vietnam showed very little improvements in the levels of educational attainment in the first half of the 20th century when they were colonized mostly by Western European countries. Thailand, which is the exception in the region and was never colonized, had been pursuing high investment in education, instituting compulsory primary education already in 1921. Although this was only partially implemented, substantial progress had been shown in literacy attainment and progression to primary education, although the abundant land endowment seemed to have been a constraint to invest strongly in education development in Thailand, in opposition to what happened in Japan and South Korea (Douangngeune et al., 2005). In the Philippines, although the Spanish government decreed in 1863 a system of free public primary education (as a way to control cultural and intellectual life) attendance was very low. However under the tutelage of the United States, primary education was extended to benefit more people.

The increase in enrolment through the six countries happened at different pace and at different time. After independence in 1946, the government of the Philippines picked up this emphasis on education and opened schools in even the remotest areas of the archipelago during the 1950s and the 1960s. Singapore started as early as 1959 with the government pursuing a clear policy of educational expansion (Mukhopadhaya, 2001a) in two main waves: in a first wave, starting in 1959, investments were increased in primary and later, secondary education, especially after 1965 (full independence). It is at the end of the 1970s that the government targeted the expansion for the post-secondary level that would permit to establish high-tech 
industries as an engine of growth (Mukhopadhaya, 2001b) with a full participation of women.

After the Dutch legacy through colonial time with low educational development, one of the first tasks of the Indonesian government was the expansion of primary and secondary school as well as adult literacy campaign (Mason et al., 2001). However, the real expansion of the education system started in 1973 with the boom of oil revenues that were in part allocated to the expansion of the primary education system that allowed universal primary education to be achieved around 1986 (Lanjouw et al., 2001).

In Thailand as mentioned before, improvements have started early and explaining that in 1970, already $94 \%$ of the population was literate, the highest rate in the region. However, a large majority of students until the beginning of the 1990s did not pursue education beyond primary education, leaving a small share to secondary education and above, pointing to the existence of a bottleneck between primary and secondary education (Jeong, 2005 \& Fan et al., 2004).

Although Malaysia has become independent since 1948, it is not until 1971 and the establishment of the New Economic Policy (NEP) that educational development was judged essential, and especially designed to enhance the economic standing of ethnic Malays and other indigenous peoples (known as "bumiputeras").

Until 1989 when Vietnam instituted the restructuring of the education system through the "doi moi" (new life), a program of overall economic renovation that includes an increase in absolute terms and as a percentage of overall government spending of the spending on education and training, the country showed very little expansion of the education system explaining why it is behind in terms of educational attainment of the others.

Despite reforms aiming at the extension to mass education, many countries suffered and are still suffering from inequality in access to education. Naranong (1998) pointed out that in Thailand the existence of a bottleneck between primary and secondary education until the beginning of the 1990s was probably due to inequality within the country for access to secondary education between rural and urban areas, the latter being handicapped in their advancement to secondary education. Also, the secondary and tertiary education sector was suffering from serious issues of curriculum relevance and quality, due to an outdated education system with teachers receiving low salaries (Sjöholm, 2002). The same is true of Indonesia where while the government extended in 1994 compulsory education to junior secondary ( 9 years of education until age 15), it seems to have failed to realize this objective especially for the rural and poor segment of the population (Behrman et al., 2002). The decentralization movement that was implemented in 1999 did not seem to be able to address the disparities and may have even increased them (Kristiansen and Pratikno, 2006 \& Bjork, 2004). Booth (2000) suggests that programs targeted to the specific needs of poor people in poor and rural areas will be essential. The Vietnamese education system does not target the poor households properly ever as they have not benefited yet from the educational expansion, for instance through membership in the Fast Track Initiative. In the Philippines, however quality seems to be an issue at the primary level where many primary pupils do not seem to 
finish the 6-year primary schooling time suggesting also that public investment did not follow population growth in the education sector.

Another specificity common to most of the six countries is the high share of the private sector at all levels of education. In Indonesia, the private sector is particularly important for higher education (Welch, 2006). However most children being privately educated are attending the Islamic schools where the fees and the quality of education are quite low (BPS et al., 2004). Most children in Vietnam are enrolled in the public sector (more than 95\%) although the private sector is developing quite rapidly, especially at the pre-school level, in vocational and technical education and tertiary level of general education (Glewwe and Patrinos, 1998 \& World Bank, 1997). One of the reasons why the Philippines were able to increase levels of enrolment at all levels of education after 1980s was the implementation of the educationcontracting scheme to allow private institutions to contravene to the lack or absence of public high schools (Behrman et al., 2002).

The present high levels of education in Singapore stems from two main factors, namely strong political commitment and governmental control over educational development, and selected migration. Most tertiary students are enrolled in sciences and engineering faculties (Sjöholm, 2002). The population in Singapore traditionally arose from migrants, coming first from India, China and other countries surrounding Singapore before World War II, and from Peninsular Malaysia after the war. At the time of independence in 1965, the government adopted several restricting and selective immigration policies: Highly qualified workers and entrepreneurs are encouraged to take up permanent residency and/or acquire Singaporean citizenship, while unskilled workers only receive short term working permits and are forced to return home after the deadline, with an exception for those that were able to upgrade their skills (Jatrana and Muy Teng, 2001).

The Malaysian government has targeted the expansion of tertiary education (mostly in science and technical universities) as the major step for Malaysia to access the status of a knowledgebased economy, and for Malaysia to become a developed nation by 2020 ( UNDP Malaysia, 2006). For example, the number of students enrolled in tertiary education doubled between 1995 and 2000 (Awang, 2004).

According to Fan et al. (2005), in the mid-1990s, Thailand was suffering from the emergence of a productivity gap with other newly industrializing nations. This pointed the government to react and it began to address issues of access and quality in secondary and higher education. A nine-year compulsory education was instituted in 1999, together with free schooling up to 12 years. As a consequence, enrollment rates began to rise.

Indonesia suffered the most in the region, together with the Philippines, from the economic crisis that threatened the region in 1997/98. School enrolment went down from 1997 to 1998 as family tried to cover educational expenses of the children most advanced rather than of the less advanced in the school hierarchy (Thomas et al., 2004). However, losses in enrolment were recovered in 1999 (Lanjouw et al., 2001). For other countries where the economic crisis 
was severe like Thailand and Malaysia, the impact on the education sector (enrolment) was moderate.

From this short summary of past developments and present situation, it arises that education has become a priority but some countries will have to eliminate some bottle necks due mostly to regional or economic disparities (low income groups) and quality of education.

\section{Methodology: Reconstructing Past Education Levels and Forecasting the Future}

The purpose of the reconstruction and projection exercise is to estimate the population by age, sex and education for the period 1970-2030. We have defined four education categories, based on the classification detailed in Lutz and Goujon (2001), namely:

1. No schooling: Applies to those who have never entered any level of formal schooling or who have completed less than one year of formal schooling

2. Primary education: Includes all of those who have entered the first level (primary) but did not go on to secondary level studies

3. Secondary education: consists of those moved to the second level of education, whether or not they completed the full course, but did not proceed to studies at the tertiary level

4. Tertiary education: All those who undertook third level studies, whether or not they completed the full course

The starting point of the reconstruction and projection work is the estimation of the population according to the education categories above-mentioned by age and sex. The information on population and education was retrieved from the latest censuses around 2000 of the countries studied except in the case of Indonesia where the data provided encountered many problems and it was felt more desirable to use the Demographic and Health Survey (DHS).

\subsection{The Past}

In a forward projection, a population increases by births and in-migration and decreases by deaths and out-migration. Conversely, in a backward projection, the population decreases by births and in-migration and increases by mortality and out-migration. Mortality and migration are the main components in backward projection. For backward projection of an age-specific population, infants born during an interim period were simply not born at the beginning of the period. Hence we do not need to worry or assume anything about fertility and infant/child mortality trends during the period. If life expectancy at the beginning of the period is known, mortality rates during a projection period can be derived using standard life tables. Using the mortality rates during a period and population distribution at the end of a period, we can estimate the number of people at the beginning of a period. In a closed population where the life tables are accurate, this method seems to be perfect. If data on migration exists, the migration component can be easily included in the backward projection. 
Contrary to forward projections of a multi-state population whose methodology is well documented and frequently applied, our literature review revealed the absence of such methodology for backward projections of a multi-state population, except for event history analysis of backward multi-state projection as the method reconstructs the past by using retrospective data. Hence, the methodology presented here to backward multi-state population projection is unique. The states are defined as levels of education attainment. They are moved backward in time from 2000 to 1970 in 5 years-steps for each sex and each 5-year age group starting at age 15 .

The methodology uses existing data on age-sex distributed population at the beginning of each 5-year period and life expectancy at birth during each 5-year period. We derived survival ratios for the five-year period ending in current year base on known life expectancy during the period. For, each five-year age-sex group, the population in different levels of education at the beginning of the current year were then backward projected using the survival ratios. The population thus obtained do not correspond to the actual population due to migration issue. However, the proportions of population in different education attainment states so obtained will be same as that of the real population as we assumed that the survival ratios for native as well as immigrated are same. Hence, we used the proportions so obtained to start the backward projection for the next (backward) period. We repeated this algorithm to obtain the backward multi state projection for years 1995, 1990... back to 1970.

The difference in mortality due to different level of education attainment was introduced in the model as the difference in life expectancy at age 15 . The educational mortality differentials are based on the analysis of samples of census data (IPUMS ${ }^{5}$ ) for more than one cycle for few countries. The analysis showed that the life expectancies at age 15 of people with no schooling, primary education and tertiary education were respectively and on average three years less, two years less and two years more compared with people with secondary education. Hence the life expectancy at age 15 was anchored at the secondary educated population and the life expectancies of the other three groups were calculated based on the estimated differentials. Some sensitivity tests showed that anchoring at secondary level was the most suitable. Finally, these life expectancies were used to obtain survival ratios for each education attainment group.

While working with the data, we faced few problems which can be grouped into methodrelated problems and data-related problems. In many cases, there were larger age groups and open-ended age group starting at 60 or 65 . We fitted a linear model of logit of education attainment progression ratio (EAPR) on age-group to extrapolate the proportions to age 95+ (needed for backward projection till 1970). While extrapolation, the extrapolated proportions were adjusted to maintain consistency with original $60+$ or $65+$ proportion. We used the same model to interpolate for 5-year age groups in case of available data in larger age groups.

5 The Integrated Public Use Microdata Series (IPUMS) are census microdata for social and economic research can be downloaded from the Minnesota Population Center at the University of Minnesota website at: http://www.ipums.umn.edu/ 
This methodology is being applied at IIASA for reconstructing the past levels of educational achievement for a large number of countries (forthcoming in 2006). In this paper, we present the results of backward projection for 6 countries Indonesia, Malaysia, Philippines, Singapore, Thailand and Vietnam. In addition, to make some comparison we present the results for India and China too.

\subsection{The Future}

The projections are made using a method that is a combination of the cohort-component projection method used for single-state populations, and an adapted form of the multi-state population projection method. This methodology has been used at IIASA in recent years for projects on Mauritius (Lutz, 1994), Cape Verde (Wils, 1996), North African countries (Yousif et al., 1996), Jordan, Syria, West Bank and Gaza Strip (Goujon, 1997), Yucatan (Goujon et al., 2000), world regions (Lutz and Goujon, 2001), and Indian administrative States (Goujon and McNay, 2003), and for a case study of three countries (Guinea, Nicaragua, and Zambia) for a working paper committed by the World Bank (Lutz et al., forthcoming)

Multi-state population projection software that incorporates the methodology mentioned above is readily available. The PDE population projection software ${ }^{6}$ has been developed at IIASA. The user can define all of the states. They can be regions, educational categories, ethnic or language groups, or other user-defined dimensions. Fertility, mortality, and migration rates can be defined separately for all states. Transitions between states can be defined by age and sex also. All age-specific rates can be defined numerically or in terms of proportional changes of already defined age-specific schedules. Rates can be changed over time by certain changing summary indicators such as total fertility rate (for fertility), life expectancy (for mortality), or net number of migrants (for migration). The starting year parameters can either be entered directly in the PDE excel spreadsheet to be read by the module. Projection results can be presented in tabular and graphical form. The graphs are either moving age pyramids over time or line graphs of total multi-state population for the projection period.

The PDE Population Projection software requires four types of input that are standard to cohort-component projections: (1) base-year data on population by age, sex, and state extracted from census and DHS data as mentioned before, (2) fertility by age and state, (3) mortality by age, sex, and state, and (4) migration by age, sex, and state. One input that is specific to multi-state population projections is the transition between states by age and sex. In this study, states are educational categories. The following tables present the base-year as well as the scenario assumptions that will be discussed later in this section.

6 The PDE Population Projection Software can be downloaded free of charge at:

http://www.iiasa.ac.at/Research/POP/pub/software.html 


\section{Fertility by education}

The multi-state population projection by education further requires the fertility rates by women's level of education. This is available in Table 1 for the year 2000. The differentials were estimated by the 2003 Bangkok training course participants based on census data (Indonesia 2000, Malaysia 2000, Singapore 2000, Thailand 2000, Vietnam 1999) or DHS (Philippines 2003).

Table 1. Total fertility rate by mothers' level of education in 2000-05 and 2025-30

\begin{tabular}{|c|c|c|c|c|c|c|}
\hline Period & Country & $\begin{array}{l}\text { No } \\
\text { Schooling }\end{array}$ & Primary & Secondary & Tertiary & Total \\
\hline $2000-05$ & \multirow{2}{*}{ Indonesia } & 2.60 & 2.70 & 2.50 & 2.50 & 2.40 \\
\hline $2025-30$ & & 2.00 & 1.90 & 1.70 & 1.54 & 1.71 \\
\hline $2000-05$ & \multirow{2}{*}{ Malaysia } & 2.13 & 3.90 & 3.57 & 2.02 & 3.10 \\
\hline $2025-30$ & & 2.10 & 2.40 & 2.20 & 1.30 & 1.84 \\
\hline $2000-05$ & \multirow{2}{*}{ Philippines } & 4.50 & 4.30 & 3.00 & 2.30 & 3.27 \\
\hline $2025-30$ & & 2.80 & 2.60 & 1.80 & 1.40 & 1.80 \\
\hline $2000-05$ & \multirow{2}{*}{ Singapore } & 4.48 & 5.46 & 1.66 & 0.7 & 1.42 \\
\hline $2025-30$ & & 2.75 & 3.00 & 1.80 & 1.16 & 1.46 \\
\hline $2000-05$ & \multirow{2}{*}{ Thailand } & 2.82 & 2.20 & 1.43 & 1.37 & 1.82 \\
\hline $2025-30$ & & 2.10 & 2.00 & 1.50 & 1.50 & 1.53 \\
\hline $2000-05$ & \multirow{2}{*}{ Vietnam } & 4.13 & 2.42 & 1.90 & 1.45 & 2.32 \\
\hline $2025-30$ & & 2.10 & 2.00 & 1.50 & 1.50 & 1.75 \\
\hline
\end{tabular}

Table 2. Life expectancies at birth in 2000-05 and 2025-30 (Source: Authors' calculations except for ${ }^{\text {a }}$ UN 2004)

\begin{tabular}{|c|c|c|c|c|c|c|c|c|c|c|c|}
\hline \multicolumn{2}{|c|}{ Life expectancy } & \multicolumn{5}{|c|}{ Male } & \multicolumn{5}{|c|}{ Female } \\
\hline Period & Country & $\begin{array}{c}\text { No } \\
\text { Schooling }\end{array}$ & Prin & Secondary ${ }^{\mathrm{a}}$ & iry & Total & $\begin{array}{c}\text { No } \\
\text { Schooling }\end{array}$ & Prir & & & Tot \\
\hline 000-05 & \multirow{2}{*}{ Indonesia } & 61.6 & 62.6 & 64.6 & 66.6 & 63.3 & 65.6 & 66.6 & 68.6 & 70.6 & 67.1 \\
\hline 025-30 & & 68.3 & 69.3 & 71.3 & 73.3 & 70.5 & 71.9 & 72.9 & 74.9 & 76.9 & 74.1 \\
\hline 2000-05 & \multirow{2}{*}{ Malaysia } & 67.8 & 68.8 & 70.8 & 72.8 & 69.8 & 72.5 & 73.5 & 75.5 & 77.5 & 74.4 \\
\hline $2025-30$ & & 72.1 & 73.1 & 75.1 & 77.1 & 74.7 & 76.8 & 77.8 & 79.8 & 81.8 & 79.4 \\
\hline 2000-05 & \multirow{2}{*}{ Philippines } & 65.1 & 66. & 68.1 & 70.1 & 67.0 & 69.4 & 70.4 & 72.4 & 74.4 & 71.4 \\
\hline $2025-30$ & & 70.5 & 71. & 73. & 75.5 & 72.9 & 75.1 & 76.1 & 78.1 & 80.1 & 77.7 \\
\hline $2000-05$ & \multirow{2}{*}{ Singapore } & 73.7 & 74. & 76.7 & 78.7 & 76.2 & 77.5 & 78.5 & 80 & 82.5 & 79.7 \\
\hline $2025-30$ & & 77.5 & 78 & 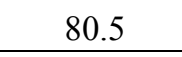 & 82.5 & 80.5 & 80.9 & 81.9 & 83.9 & 85.9 & 83.8 \\
\hline 2000-05 & \multirow{2}{*}{ Thailand } & 63.0 & 64.0 & 66.0 & 68.0 & 64.6 & 70.7 & 71.7 & 73.7 & 75.7 & 72.2 \\
\hline $2025-30$ & & 70.6 & 71.6 & 73.6 & 75.6 & 72.9 & 76.1 & 77.1 & 79.1 & 81.1 & 78.4 \\
\hline 2000-05 & \multirow{2}{*}{ Vietnam } & 65.4 & 66.4 & 68.4 & 70.4 & 66.8 & 69.4 & 70.4 & 72.4 & 74.4 & 70.6 \\
\hline $2025-30$ & & 71.2 & 72.2 & 74.2 & 76.2 & 73.0 & 75.1 & 76.1 & 78.1 & 80.1 & 76.8 \\
\hline
\end{tabular}

\section{Mortality by education}

Mortality is also considered by age, sex and education. Although information on educational mortality differentials is generally much more difficult to obtain than on fertility differentials 
and were not available for the Southeast Asian countries, we have implemented some differentials as explained in section 3.1. Therefore, we used life expectancies estimated by the United Nations (2004) to which we used MORTPAK to fit some mortality rates. These rates were anchored at the secondary level of education. The mortality rates for the other education groups were derived by scaling up or down the mortality rates according to life expectancies according to the differentials defined in section 3.1. Table 2 presents the resulting life expectancies used in the work.

\section{Migration by education}

As with population projections in general, migration assumptions are the most difficult because migration flows tend to be the most volatile. Age and education profiles of migrants are sometimes available from censuses or surveys, but the information from sending countries is usually not good. However, since past data are only of very limited use in defining migration assumptions, this is not much of an additional obstacle. For the projections that follow, some differentials for the allocation of migrants between education categories were defined based on the knowledge that the majority of migrants from developing countries belong to the middle education group as opposed to the low (too poor to migrate) or high education group (no need to migrate and a small population). Hence $10 \%$ were attributed to each the no schooling and the tertiary education category and $40 \%$ each to the primary and secondary education category (see Table 3 ). The total net migration numbers were extracted from the UN estimates for the period 2000-2030.

Table 3. Net number of migrants per year in thousand in 2000-05 and 2025-30 (Source: UN 2004)

\begin{tabular}{|l|l|l|}
\hline Period & Country & Migrants \\
\hline $2000-05$ & \multirow{2}{*}{ Indonesia } & -200 \\
$2025-30$ & & -160 \\
\hline $2000-05$ & \multirow{2}{*}{ Malaysia } & +30 \\
\cline { 1 - 1 } $2025-30$ & & +10 \\
\hline $2000-05$ & \multirow{2}{*}{ Philippines } & -180 \\
\cline { 1 - 1 } $2025-30$ & & -180 \\
\hline $2000-05$ & \multirow{2}{*}{ Singapore } & +40 \\
\cline { 1 - 1 } $2025-30$ & & +25 \\
\hline $2000-05$ & \multirow{2}{*}{ Thailand } & -10 \\
\hline $2025-30$ & & -10 \\
\hline $2000-05$ & \multirow{2}{*}{ Vietnam } & -40 \\
\hline & & -40 \\
\hline $2025-30$ & & \\
\hline
\end{tabular}

\section{Transitions between educational states}

The key parameters of the model are the age- and sex-specific educational transition rates, i.e., the age-specific intensities for young men or women to move, e.g., from the category of primary educational attainment to that of secondary attainment. Data on these rates are seldom available, and have to be estimated. The set of necessary transition rates is very limited because education is hierarchical, e.g., persons can only move to the next higher category. 
Transitions also occur over a short period of time and only for the few age groups that are in school (usually from five to at most 24 years of age), as the phenomenon of adult education is rather minimal. The best data that would allow the calculation of precise transition rates would be levels of enrolment detailed by age, level of schooling, and sex. In this case, the calculation of transition rates is very simple. However, most of the time the age structure is not available and needs to be estimated from the levels of educational attainment at each age and education levels, translating cohort data in age groups 5-9, 10-14, 15-19, 20-24 into period data. Estimated transition probabilities are described in Table 4.

Table 4. Transition probabilities in 2000-05 and 2030 (scenario Trend)

\begin{tabular}{|c|c|c|c|c|c|c|c|c|c|c|c|c|c|}
\hline \multicolumn{2}{|l|}{ Transition } & \multicolumn{4}{|c|}{$\begin{array}{l}\text { From 'No schooling' } \\
\text { To } \\
\text { 'Primary' }\end{array}$} & \multicolumn{4}{|c|}{$\begin{array}{l}\text { From 'Primary' } \\
\text { To } \\
\text { 'Secondary' }\end{array}$} & \multicolumn{4}{|c|}{$\begin{array}{l}\text { From 'Secondary' } \\
\text { To } \\
\text { 'Tertiary' }\end{array}$} \\
\hline \multicolumn{2}{|l|}{$\frac{\text { Sex }}{\text { Age-group }}$} & \multicolumn{2}{|c|}{ Male } & \multicolumn{2}{|c|}{ Female } & \multicolumn{2}{|c|}{ Male } & \multicolumn{2}{|c|}{ Female } & \multicolumn{2}{|c|}{ Male } & \multicolumn{2}{|c|}{ Female } \\
\hline Age-group & & $\begin{array}{l}5- \\
9\end{array}$ & $10-14$ & $\begin{array}{l}5- \\
9\end{array}$ & $\begin{array}{l}10- \\
14\end{array}$ & $\begin{array}{l}10- \\
14\end{array}$ & $\begin{array}{l}15- \\
19\end{array}$ & $\begin{array}{l}10- \\
14\end{array}$ & $\begin{array}{l}15- \\
19\end{array}$ & $\begin{array}{l}15- \\
19\end{array}$ & $\begin{array}{l}20- \\
24\end{array}$ & $\begin{array}{l}15- \\
19\end{array}$ & $\begin{array}{l}20- \\
24\end{array}$ \\
\hline \multirow{2}{*}{ Indonesia } & & 0.85 & 0.91 & 0.85 & 0.94 & 0.38 & 0.60 & 0.43 & 0.59 & 0.07 & 0.13 & 0.10 & 0.14 \\
\hline & & .85 & 0.91 & 0.85 & 0.94 & 0.53 & 0.8 & 0.6 & 0. & 0.1 & .3 & 0.25 & .35 \\
\hline \multirow{2}{*}{ Malaysia } & & 0.64 & 0.94 & 0.67 & 0.94 & 0.67 & 0.89 & 0.6 & 0. & 0.26 & 0.23 & 0.35 & .25 \\
\hline & & .64 & 0.94 & 0.67 & 0.94 & 0.67 & 0.89 & 0.6 & 0 . & 0.42 & 0.37 & 0.51 & 0.37 \\
\hline \multirow{2}{*}{ Philippines } & & .73 & 0.91 & 0.76 & 0. & 0.26 & 0.6 & 0 & 0 & 0.70 & 0.18 & 0.79 & 0.22 \\
\hline & & 0.73 & 0.91 & 0.76 & 0.92 & 0.36 & 0.91 & 0.2 & 0. & 0.89 & 0.23 & 1.01 & 0.28 \\
\hline \multirow{2}{*}{ Singapore } & & 1.00 & & 1.00 & & 0.44 & 0.98 & 0. & 0. & 0.38 & .41 & 0.45 & 0.50 \\
\hline & & 1.00 & & 1.00 & & 0.44 & 0.98 & 0.44 & 0 . & 0.48 & 0.52 & 0.57 & 0.64 \\
\hline \multirow{2}{*}{ Thailand } & & 0.80 & 0.92 & 0.83 & 0.93 & 0.25 & 0.74 & 0.27 & 0.8 & 0.14 & 0.38 & 0.18 & 0.47 \\
\hline & $2025-30$ & 0.84 & 0.97 & 0.87 & 0.98 & 0.28 & 0.82 & 0.30 & 0.88 & 0.20 & 0.53 & 0.20 & 0.52 \\
\hline \multirow{2}{*}{ Vietnam } & $2000-5$ & 0.74 & 0.85 & 0.74 & 0.84 & 0.07 & 0.49 & 0.0 & 0.45 & 0.17 & 0.18 & 0.17 & 0.18 \\
\hline & $2025-30$ & 0.82 & 0.94 & 0.82 & 0.93 & 0.11 & 0.79 & 0.13 & 0.72 & 0.27 & 0.29 & 0.27 & 0.29 \\
\hline
\end{tabular}

\section{Scenarios}

The projections were implemented according to two scenarios: "Constant" and "Trend' scenario. The two scenarios differ only by the education assumptions for the future. Indeed, both scenarios follow the same paths in terms of fertility, mortality and migration. The assumptions concerning those are shown in tables 1 to 3 . In the constant scenario, we suppose that the transition probabilities of moving from one education category to the next will remain constant at levels observed in 2000. This scenario is helpful to see the progress already embedded into the population as the transition probabilities for the starting year reflect approximately the present enrolment rates In the trend scenario, we calculate based on a logarithmic trend the changes in levels of education in the younger cohorts by sex to calculate some trends of how fast the levels of educational attainment were improving or declining. This trend is then applied to the present transition probabilities up to the period 2025-30 (see Table 4). 


\section{Results: Levels of educational attainment from 1970 to 2030}

This will be presented in two sections divided between past and future levels of educational attainment. The results are summarized in a series of population pyramids for all six countries in the Annex.

\subsection{The Past}

As mentioned in section 2, all countries have seen a relative large increase in the percentage of educated population aged 20-64 between 1970 and 2000 as can be seen from the decline in the proportions of the population with no education who is usually a vulnerable group within a country. In 1970, it ranged from 10 percent in the Philippines - which were an outlier in the region - to 54 percent in Singapore. The six Southeast Asian countries have converged to similar levels of adult population without education: from $2 \%$ in the Philippines to 12 percent in Singapore. The gap between male and female is still present in 2000. For instance, women in Indonesia had shares of their population without education higher than men by seven percentage points. Presently, Southeast Asian countries seems to be doing better than India in terms of working age population who have been schooled, which is catching up slowly, and at levels close to that of China, although the history of China literacy campaign is much more recent pointing to a process of rapid catching up.

Table 5. Proportion 15-24 with no education, male and female, 1970-2000 (Authors' calculations)

\begin{tabular}{|l|l|r|r|r|r|}
\hline Country & Sex & 1970 & 1980 & 1990 & 2000 \\
\hline Indonesia & Male & 8.0 & 5.2 & 2.0 & 1.0 \\
\cline { 2 - 6 } & Female & 22.4 & 12.2 & 3.7 & 1.2 \\
\hline Malaysia & Male & 8.9 & 6.1 & 4.8 & 2.8 \\
\cline { 2 - 6 } & Female & 20.6 & 10.5 & 5.8 & 2.7 \\
\hline Philippines & Male & 3.4 & 2.5 & 1.8 & 1.6 \\
\cline { 2 - 6 } & Female & 4.0 & 2.9 & 2.0 & 1.5 \\
\hline Singapore & Male & 14.5 & 8.9 & 4.5 & 1.5 \\
\cline { 2 - 6 } Thailand & Female & 26.4 & 11.0 & 4.1 & 1.2 \\
\hline \multirow{3}{*}{ Vietnam } & Male & 8.5 & 5.9 & 4.3 & 2.7 \\
\cline { 2 - 6 } & Female & 12.7 & 7.9 & 4.6 & 2.5 \\
\cline { 2 - 6 } & Male & 4.5 & 3.8 & 5.5 & 5.7 \\
\cline { 2 - 6 } & Female & 11.6 & 6.9 & 6.5 & 5.8 \\
\hline
\end{tabular}

The 20-64 age group is quite large and its level of educational attainment reflects mostly past educational and enrolment policy, as are included in this indicator younger and older generations of the living population. One way to look at the new trends in terms of acquiring education is to look at the proportion without education in the youngest age group that is the 15-24. This is shown in Table 5. It shows that entrance to primary education is almost universally achieved for the younger age group at levels of 1.1\% (Indonesia) and above. A look in the past shows that if schooling seemed to be acquired already in the 1970 s for the young adult male, this conquest is more recent for the female. In 1970 , more than $20 \%$ of the 
young female population of Indonesia, Malaysia and Singapore did not receive any schooling. It is interesting that the poor countries such as Vietnam and Philippines seemed to have achieved the overall levels of enrolment in primary school as their wealthier neighbors in Singapore.

The difference in levels of educational attainment is very noticeable. There seem to be two main typologies of educational attainment. In the first group (Malaysia, Philippines, and Singapore) the working age population in 2000 was in majority in the secondary and higher education categories. In this group, Malaysia is the country that experienced the largest increase as the proportion with secondary and more increased from 18 percent in 1970 to 68 percent in 2000. The Malaysian experience is close to that of China. One should not forget the case of the Philippines where already in 1970, more than 30\% had more than a secondary education. The second group includes Indonesia, Thailand and Vietnam where there still seemed to be a predominance of working age people with primary education and less. India is in that group too.

The figures for tertiary education show the lesser improvements over the back-projection period with larger differences in the shares of working age population in the less developed countries of the region (Indonesia and Vietnam at levels comparable to that of China and India) between 5-8 percent. Richer countries such as Malaysia, Singapore, Philippines and Thailand have rather high tertiary enrolment rates: $15 \%$ for Malaysia, $14 \%$ for Thailand, $24 \%$ for the Philippines and $28 \%$ for Singapore. Malaysia is investing heavily in tertiary education as it receives $35 \%$ of the total education expenditures (UNESCO, 2004).

To make comparison easier, we calculated average years of schooling (Table 12) for the population by weighing the duration of schooling by age-sex-education specific distribution. Philippines stood first with an average of 7 years of schooling. The worst situation was in Singapore with 4.1 years followed by Vietnam (4.2 years), Indonesia (4.3 years), Malaysia (4.9 years) and Thailand (5.3 years).

At the end of the $20^{\text {th }}$ century, the education status in terms of average years of schooling for the population aged 20-64 increased in all the countries (Table 12). However, the pace of change was different between the countries. The average years of schooling more than doubled in Malaysia (11.1 years) and in Singapore (9.3 years). In Philippines, the increase in average years of schooling was slow with an increase of 2.3 years (from 7.0 years to 9.3 years). The lesser increases were observed in Vietnam ( 7.0 years), followed by Indonesia ( 8.4 years) and Thailand (8.9 years). (Figure 1a-1h, Table 6-11). To analyse the education attainment in gender perspective, we used the ratio of mean years of schooling of female to that of male. In the beginning of 1970, all countries had the value of this ratio less than 1, implying female were less educated in terms of numbers and/or duration of education than male. Philippines had the maximum value of the ratio, 0.94, in 1970, followed by Thailand (0.78), Singapore (0.60), Malaysia (0.60), Vietnam (0.58) and Indonesia (0.57). China and India had ratio of 0.52 and 0.35 . The ratio increased with time for all countries and in 2000, Philippines exceeded one in 1995 and in 2000 the ratio was 1.02. For all countries, this ratio 
was getting closer to one with Thailand (0.94), Singapore (0.91), Malaysia (0.91), Vietnam (0.89) and Indonesia (0.87). The value for China and India were 0.84 and 0.57.

What comes clear from the description of the results from the reconstruction of past educational attainment is that the group of countries that were chosen are clearly determined in investing in education. This is especially the case of Singapore, Malaysia, Thailand, the Philippines and perhaps also Vietnam. Indonesia is a country apart as some of its performance in terms of enrolments and investments are rather weak. Indonesia has expanded strongly the education system in the 1970s after the oil boom but did not manage to improve the quality of education as well as the participation and relevance of tertiary studies. Some of the weaker results in education outputs especially educational attainment may be due to the momentum of education - that is the lag between educational investments and the translation into human capita throughout the labour force. This is the case for a wealthy country such as Singapore where some of the labour force is still illiterate, although income level is comparable to Europe or Japan. Education does not jump and one cannot erase so easily decades of neglect in education. Singapore has compensated its lack of human skills by opening the borders to workers. The literature shows that the expansion of the education systems in these countries did not go without problems related to quality or adequacy. This is the case of tertiary in Thailand and Malaysia where most students graduate in humanities, arts, social science, business and law and too few in science and engineering. This necessity to not only look at number of population but also at the quality and curriculum will be kept in mind when projecting the future educational level of the population. 
Figures 1a-1h. Proportion of people age 20-64 by education attainment and average years of schooling in six Southeast Asian countries, China and India (1970-2000)

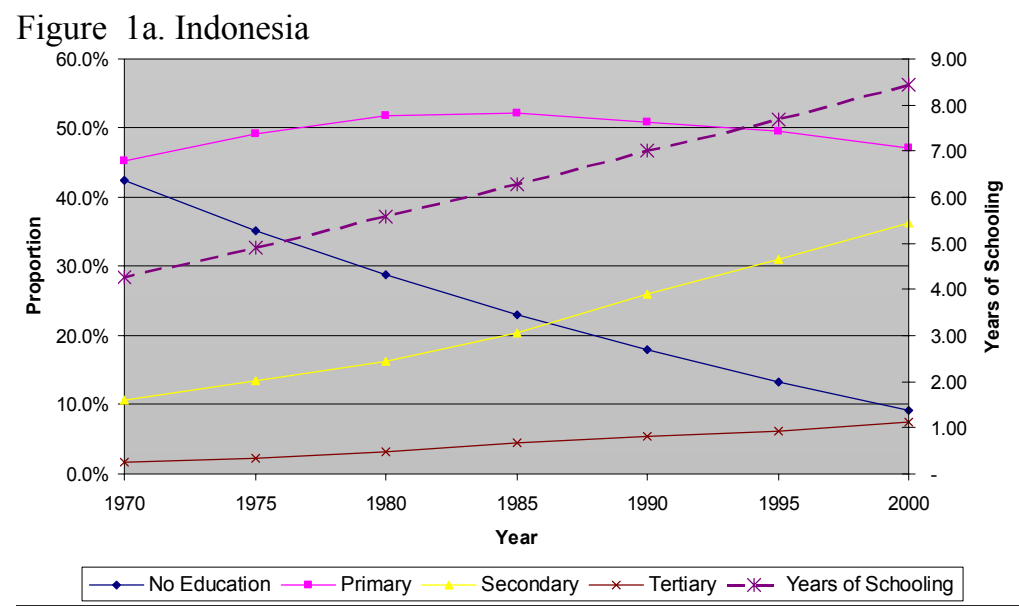

Figure 1b. Malaysia

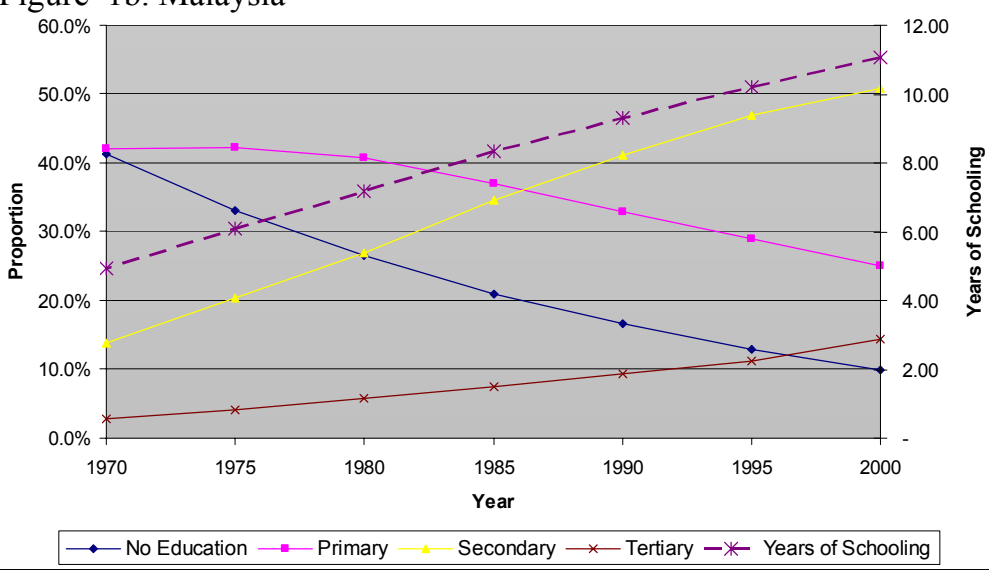

Figure 1c. The Philippines

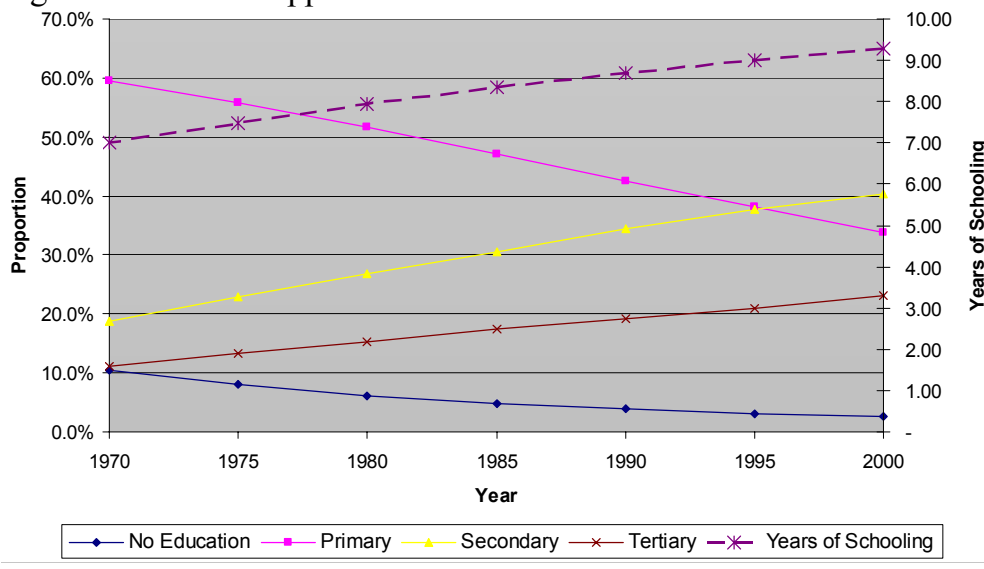


Figure 1d. Singapore

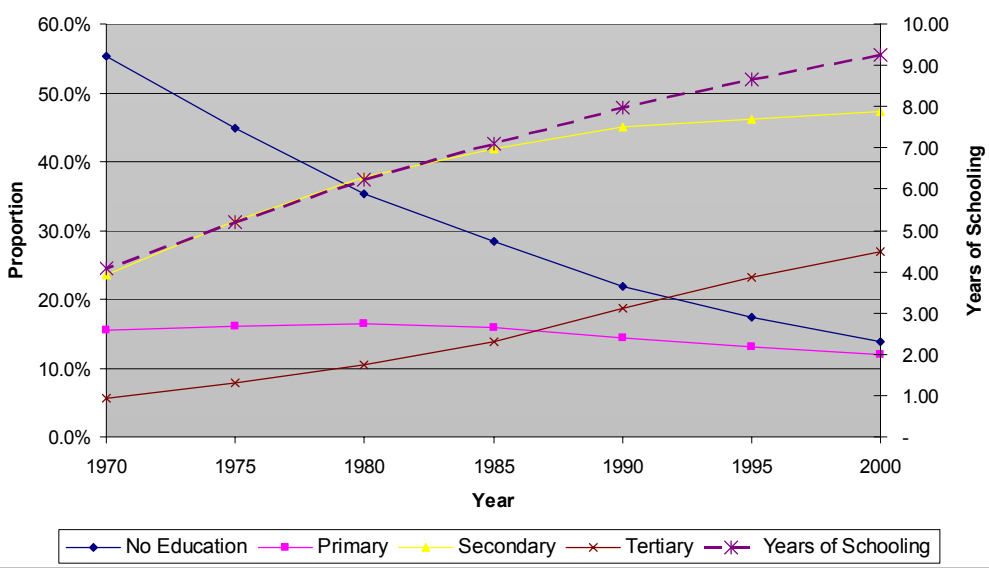

Figure 1e. Thailand

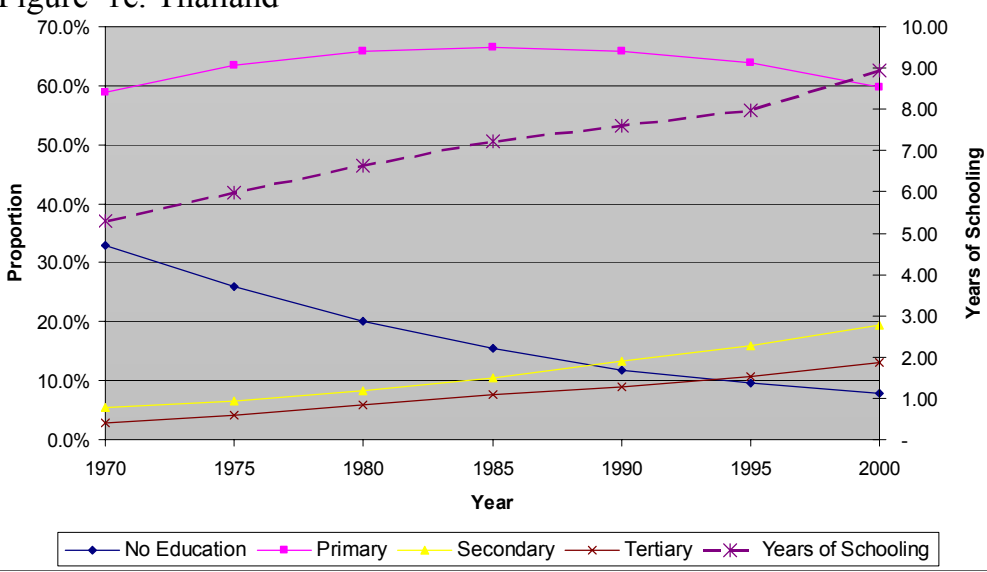

Figure 1f. Vietnam

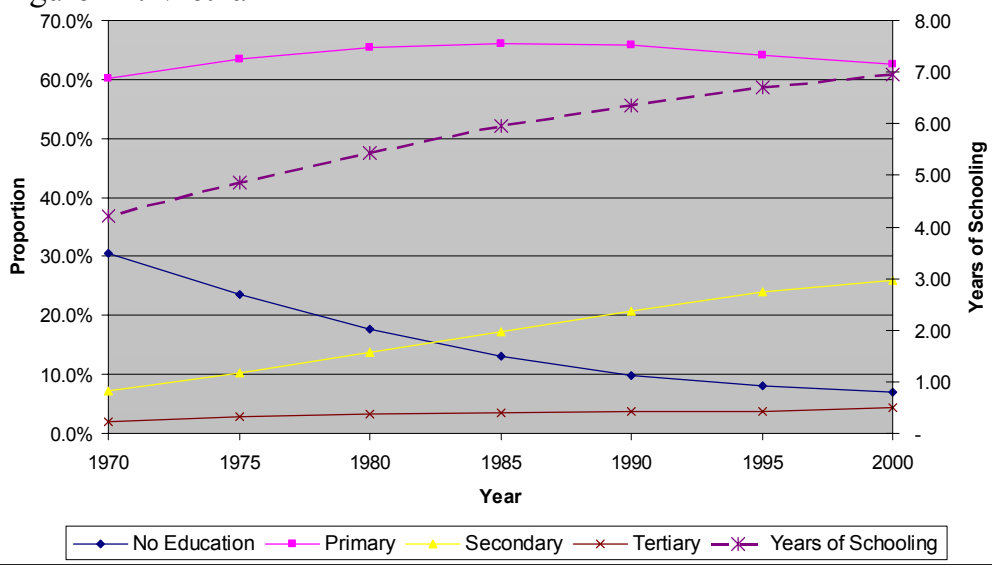



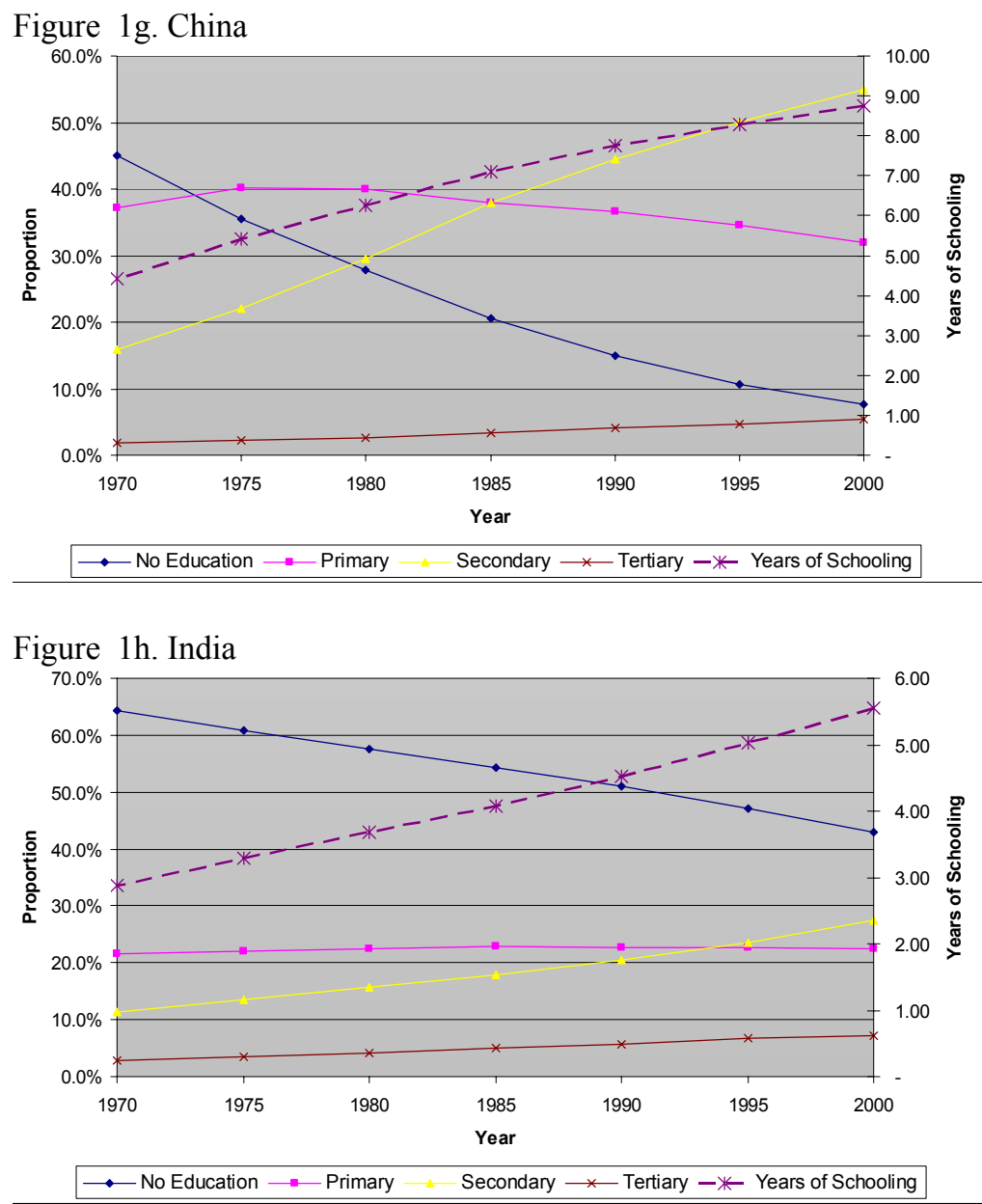

\subsection{The Future}

Illiteracy -- approximated from the proportion of the population in the no education group--will decline importantly in the next 25 years as shown from tables 6 to 11. All countries will have more than $95 \%$ of their working age population male and female population literate. In the Philippines and Indonesia, the literacy rate will be below $2 \%$ of the population. In Singapore, the decline in the working age female population with no schooling will be particularly drastic, from 16.4 in 2000 to $3.4 \%$ in 2030. Some communities that are not reached by education can explain the persistence of some pockets of illiteracy even under the trend scenario. Those are particularly at risk in the case of an economic crisis. In Singapore and Malaysia, migration is the main responsible for the existence of a non-educated population. This might change as countries of origin develop further access to primary education. 
If the Southeast region is quite homogenous regarding the weight of the working age population with no schooling, countries seem to diverge when it comes to levels of educational attainment. There are several patterns of change in the level of educational attainment in the future that reflect the emphasis of the education development policy in the recent years. In Indonesia, in 2000, the bulk of the working age population was in the primary education group: around 47 percent. In 2030, there will be a shift of the working age population to secondary education with about $55 \%$ in that group. As can be seen from Table 6 , this will happen rather quickly within the next 10 years.

Table 6. Education attainment of population20-64 in Indonesia, 1970-2030

\begin{tabular}{|c|c|c|c|c|c|c|c|c|c|}
\hline \multirow{2}{*}{\multicolumn{2}{|c|}{ Education }} & \multicolumn{2}{|c|}{ No Schooling } & \multicolumn{2}{|c|}{ Primary } & \multicolumn{2}{|c|}{ Secondary } & \multicolumn{2}{|c|}{ Tertiary } \\
\hline & & Male & Female & Male & Female & Male & Female & Male & Female \\
\hline \multicolumn{2}{|c|}{1970} & 27.9 & 56.7 & 55.4 & 35.3 & 14.1 & 7.2 & 2.6 & 0.7 \\
\hline \multicolumn{2}{|c|}{1980} & 17.7 & 39.7 & 57.1 & 46.4 & 20.6 & 11.9 & 4.6 & 2.0 \\
\hline \multicolumn{2}{|c|}{1990} & 10.5 & 25.2 & 51.9 & 49.8 & 31.0 & 20.9 & 6.6 & 4.1 \\
\hline \multicolumn{2}{|c|}{2000} & 5.2 & 12.2 & 45.9 & 48.6 & 40.6 & 32.3 & 8.3 & 6.9 \\
\hline \multirow{2}{*}{2010} & Constant & 2.8 & 5.9 & 39.2 & 42.0 & 48.5 & 42.6 & 9.5 & 9.4 \\
\hline & Trend & 2.8 & 5.9 & 39.2 & 42.0 & 48.2 & 42.3 & 9.8 & 9.7 \\
\hline \multirow{2}{*}{2020} & Constant & 1.9 & 3.1 & 33.6 & 36.1 & 54.1 & 49.7 & 10.4 & 11.1 \\
\hline & Trend & 1.9 & 3.1 & 32.5 & 35.0 & 53.3 & 48.6 & 12.4 & 13.3 \\
\hline \multirow{2}{*}{2030} & Constant & 1.2 & 1.3 & 29.4 & 30.3 & 58.6 & 56.0 & 10.8 & 12.5 \\
\hline & Trend & 1.2 & 1.3 & 25.5 & 26.4 & 56.7 & 53.1 & 16.7 & 19.2 \\
\hline
\end{tabular}

Malaysia in comparison with Indonesia levels of educational attainment of the working age population is rather more advanced (table 7 ). In 2000 , already $54 \%$ of the male and $48 \%$ of the female had entered secondary education whereas only $25 \%$ had a primary education. The share of the population with only primary education will decline to $7.5 \%$ by 2030 . According to the trend scenario, this will be the lowest percentage of the population in primary among the six Southeast Asian countries. The proportion of the population with some secondary education will not be very different than in 2000 , although the gap between men and women at this level will be almost closed. This stagnation masks an important shift to the tertiary sector of the education system where $34 \%$ of the working age population will have studied.

The pattern of educational change in the Philippines is rather similar to that of Malaysia with the growing importance of the tertiary educated in the working age population (Table 8). The main difference between the two countries is in the proportion of the population with a primary education, which seems to be greater in the Philippines than in Malaysia both in 2000 and in 2030: $22 \%$ of males and $14 \%$ of females 
Table 7. Education attainment of population20-64 in Malaysia, 1970-2030

\begin{tabular}{|c|c|c|c|c|c|c|c|c|c|}
\hline \multirow{2}{*}{\multicolumn{2}{|c|}{ Education }} & \multicolumn{2}{|c|}{ No Schooling } & \multicolumn{2}{|c|}{ Primary } & \multicolumn{2}{|c|}{ Secondary } & \multicolumn{2}{|c|}{ Tertiary } \\
\hline & & Male & Female & Male & Female & Male & Female & Male & Female \\
\hline \multicolumn{2}{|c|}{1970} & 29.1 & 53.7 & 48.6 & 35.2 & 18.2 & 9.5 & 4.1 & 1.5 \\
\hline \multicolumn{2}{|c|}{1980} & 17.8 & 35.2 & 42.7 & 38.7 & 31.8 & 22.2 & 7.6 & 3.8 \\
\hline \multicolumn{2}{|c|}{1990} & 11.3 & 22.2 & 32.7 & 32.9 & 44.9 & 37.2 & 11.1 & 7.6 \\
\hline \multicolumn{2}{|c|}{2000} & 7.0 & 12.7 & 24.2 & 25.6 & 53.9 & 48.0 & 14.9 & 13.8 \\
\hline \multirow{2}{*}{2010} & Constant & 4.5 & 7.0 & 16.4 & 18.0 & 58.8 & 53.9 & 20.3 & 21.2 \\
\hline & Trend & 4.5 & 7.0 & 16.4 & 18.0 & 58.5 & 53.6 & 20.6 & 21.4 \\
\hline \multirow{2}{*}{2020} & Constant & 3.4 & 4.3 & 11.1 & 11.6 & 61.4 & 57.5 & 24.1 & 26.7 \\
\hline & Trend & 3.4 & 4.3 & 11.1 & 11.6 & 59.4 & 55.8 & 26.2 & 28.4 \\
\hline \multirow{2}{*}{2030} & Constant & 2.7 & 2.8 & 8.0 & 7.3 & 62.1 & 58.7 & 27.1 & 31.3 \\
\hline & Trend & 2.7 & 2.8 & 8.0 & 7.3 & 56.8 & 54.0 & 32.5 & 35.9 \\
\hline
\end{tabular}

Table 8. Education attainment of population20-64 in Philippines, 1970-2030

\begin{tabular}{|c|r|r|r|r|r|r|r|r|r|}
\hline \multirow{2}{*}{ Education } & \multicolumn{2}{|c|}{ No Schooling } & \multicolumn{2}{c|}{ Primary } & \multicolumn{2}{c|}{ Secondary } & \multicolumn{2}{c|}{ Tertiary } \\
\cline { 3 - 10 } & Male & Female & Male & Female & Male & Female & Male & Female \\
\hline \multicolumn{2}{|c|}{1970} & 9.5 & 11.6 & 57.8 & 61.4 & 20.9 & 16.7 & 11.7 & 10.3 \\
\hline 1980 & 5.5 & 6.8 & 50.3 & 53.2 & 28.5 & 25.0 & 15.7 & 15.0 \\
\hline \multicolumn{2}{|c|}{1990} & 3.5 & 4.2 & 42.1 & 42.1 & 35.6 & 33.3 & 18.8 & 19.8 \\
\hline 2000 & 2.5 & 2.8 & 35.3 & 33.0 & 40.6 & 39.9 & 21.6 & 24.4 \\
\hline \multirow{2}{*}{2010} & Constant & 1.9 & 1.9 & 30.8 & 25.6 & 44.0 & 44.1 & 23.3 & 28.4 \\
\cline { 2 - 10 } & Trend & 1.9 & 1.9 & 30.8 & 25.6 & 43.9 & 44.0 & 23.4 & 28.5 \\
\hline 2020 & Constant & 1.8 & 1.6 & 28.1 & 21.0 & 46.0 & 46.6 & 24.1 & 30.8 \\
\cline { 2 - 9 } & Trend & 1.8 & 1.6 & 26.3 & 19.6 & 46.5 & 46.6 & 25.4 & 32.2 \\
\hline 2030 & Constant & 1.7 & 1.3 & 26.8 & 18.3 & 47.0 & 48.0 & 24.5 & 32.4 \\
\cline { 2 - 9 } & Trend & 1.7 & 1.3 & 21.6 & 14.4 & 48.6 & 47.9 & 28.2 & 36.3 \\
\hline
\end{tabular}

Table 9. Education attainment of population20-64 in Singapore, 1970-2030

\begin{tabular}{|c|c|c|c|c|c|c|c|c|c|}
\hline \multirow{2}{*}{\multicolumn{2}{|c|}{ Education }} & \multicolumn{2}{|c|}{ No Schooling } & \multicolumn{2}{|c|}{ Primary } & \multicolumn{2}{|c|}{ Secondary } & \multicolumn{2}{|c|}{ Tertiary } \\
\hline & & Male & Female & Male & Female & Male & Female & Male & Female \\
\hline \multicolumn{2}{|c|}{1970} & 45.3 & 66.1 & 18.2 & 12.5 & 28.8 & 18.0 & 7.7 & 3.3 \\
\hline \multicolumn{2}{|c|}{1980} & 27.6 & 43.2 & 17.2 & 15.7 & 41.5 & 33.8 & 13.7 & 7.3 \\
\hline \multicolumn{2}{|c|}{1990} & 17.3 & 26.5 & 14.3 & 14.5 & 45.9 & 44.0 & 22.4 & 15.0 \\
\hline \multicolumn{2}{|c|}{2000} & 10.8 & 16.4 & 11.3 & 12.3 & 47.8 & 46.5 & 30.1 & 24.8 \\
\hline \multirow[t]{2}{*}{2010} & Constant & 6.8 & 9.2 & 11.7 & 13.0 & 48.0 & 46.7 & 33.5 & 31.1 \\
\hline & Trend & 6.8 & 9.2 & 11.7 & 13.0 & 47.8 & 46.5 & 33.7 & 31.3 \\
\hline \multirow[t]{2}{*}{2020} & Constant & 4.8 & 5.2 & 11.2 & 11.9 & 46.2 & 44.5 & 37.9 & 38.5 \\
\hline & Trend & 4.8 & 5.2 & 11.2 & 11.9 & 45.1 & 43.3 & 39.0 & 39.7 \\
\hline \multirow[t]{2}{*}{2030} & Constant & 3.4 & 3.4 & 10.2 & 10.4 & 44.8 & 40.5 & 41.6 & 45.7 \\
\hline & Trend & 3.4 & 3.4 & 10.2 & 10.4 & 41.9 & 37.2 & 44.5 & 49.0 \\
\hline
\end{tabular}

Singapore has a unique pattern of educational development. It combines in 2000, quite high proportion of the working age population in the no schooling category (in the older working age categories) and at the same time almost $47 \%$ with some secondary education. In 2030 , the picture will have changed even more as the bulk of the working age population will have a tertiary education: again 47 percent (Table 9). 
Thailand will witness a similar shift from the primary education group to the secondary education group similar to that observed in Indonesia. However at the same time, Thailand will increase the share of the working age population with tertiary education to levels similar to that of Malaysia. The catching up process in Thailand was very much in place in 2000 already. In 2030, Thailand should have $38 \%$ of it working age population with a secondary education and $34 \%$ with a tertiary education, which represents a rapid increase if we consider that there were respectively only $19 \%$ and $13 \%$ in 2000 (Table 10).

Table 10. Education attainment of population20-64 in Thailand, 1970-2030

\begin{tabular}{|c|c|c|c|c|c|c|c|c|c|}
\hline \multirow{2}{*}{\multicolumn{2}{|c|}{ Education }} & \multicolumn{2}{|c|}{ No Schooling } & \multicolumn{2}{|c|}{ Primary } & \multicolumn{2}{|c|}{ Secondary } & \multicolumn{2}{|c|}{ Tertiary } \\
\hline & & Male & Female & Male & Female & Male & Female & Male & Female \\
\hline \multicolumn{2}{|c|}{1970} & 26.6 & 39.1 & 62.1 & 55.8 & 7.8 & 3.0 & 3.5 & 2.0 \\
\hline \multicolumn{2}{|c|}{1980} & 16.0 & 24.2 & 66.0 & 65.5 & 11.3 & 5.2 & 6.7 & 5.0 \\
\hline \multicolumn{2}{|c|}{1990} & 9.6 & 14.1 & 64.2 & 67.4 & 16.4 & 9.9 & 9.4 & 8.5 \\
\hline \multicolumn{2}{|c|}{2000} & 6.4 & 9.0 & 58.0 & 61.4 & 22.8 & 16.2 & 12.8 & 13.4 \\
\hline \multirow[t]{2}{*}{2010} & Constant & 4.4 & 5.6 & 46.8 & 49.6 & 30.3 & 23.6 & 18.4 & 21.2 \\
\hline & Trend & 4.4 & 5.6 & 46.8 & 49.6 & 30.1 & 23.5 & 18.7 & 21.3 \\
\hline \multirow[t]{2}{*}{2020} & Constant & 3.2 & 3.7 & 37.5 & 38.6 & 36.5 & 30.0 & 22.8 & 27.7 \\
\hline & Trend & 3.2 & 3.7 & 37.1 & 38.2 & 35.3 & 29.7 & 24.5 & 28.4 \\
\hline \multirow[t]{2}{*}{2030} & Constant & 2.3 & 2.3 & 29.0 & 27.3 & 41.9 & 36.4 & 26.8 & 34.0 \\
\hline & Trend & 2.2 & 2.1 & 27.7 & 26.0 & 38.9 & 35.9 & 31.2 & 36.0 \\
\hline
\end{tabular}

The trend scenario does not allow for Vietnam to catch up with its neighbours by 2030 (Table 11). In fact, Vietnam's share of the working age population in the primary and secondary education group will be very close to that of Indonesia in 2000. However this trend scenario may hide some rapid change that could occur if the economic development is particularly beneficial and if the need for tertiary educated population becomes more important to the economy. Vietnam is also the country where the gender gap is the largest of the region.

Table 11. Education attainment of population20-64 in Vietnam, 1970-2030

\begin{tabular}{|c|c|c|c|c|c|c|c|c|c|}
\hline \multirow{2}{*}{\multicolumn{2}{|c|}{ Education }} & \multicolumn{2}{|c|}{ No Schooling } & \multicolumn{2}{|c|}{ Primary } & \multicolumn{2}{|c|}{ Secondary } & \multicolumn{2}{|c|}{ Tertiary } \\
\hline & & Male & Female & Male & Female & Male & Female & Male & Female \\
\hline \multicolumn{2}{|c|}{1970} & 16.7 & 44.1 & 68.5 & 52.1 & 11.3 & 3.2 & 3.5 & 0.7 \\
\hline \multicolumn{2}{|c|}{1980} & 9.1 & 25.9 & 67.3 & 63.5 & 19.0 & 8.7 & 4.7 & 1.9 \\
\hline \multicolumn{2}{|c|}{1990} & 5.5 & 14.2 & 64.3 & 67.3 & 25.4 & 16.0 & 4.7 & 2.5 \\
\hline \multicolumn{2}{|c|}{2000} & 5.1 & 8.7 & 60.2 & 65.0 & 29.4 & 22.5 & 5.2 & 3.7 \\
\hline \multirow[t]{2}{*}{2010} & Constant & 4.8 & 6.3 & 55.0 & 59.6 & 33.5 & 28.3 & 6.7 & 5.8 \\
\hline & Trend & 4.8 & 6.3 & 55.0 & 59.6 & 33.4 & 28.2 & 6.9 & 5.9 \\
\hline \multirow[t]{2}{*}{2020} & Constant & 4.5 & 5.3 & 51.9 & 55.8 & 36.0 & 32.0 & 7.6 & 6.9 \\
\hline & Trend & 4.5 & 5.3 & 50.1 & 54.2 & 36.6 & 32.6 & 8.8 & 8.0 \\
\hline \multirow[t]{2}{*}{2030} & Constant & 4.4 & 4.8 & 49.2 & 52.4 & 37.9 & 34.9 & 8.5 & 7.9 \\
\hline & Trend & 4.0 & 4.4 & 43.1 & 46.8 & 40.6 & 37.4 & 12.3 & 11.5 \\
\hline
\end{tabular}


It is important to note that according to the trend in place at the moment women will have more rapid increase in the rate of educational attainment than men and this will be very visible in those women with some tertiary education. In all countries, to the exception of Vietnam, the proportion of female working age population with tertiary education will be higher than that of men. It would be however important to modulate this with the completed levels of tertiary education. In Europe, women are more to enter tertiary studies but often drop out without completing any levels resulting in a higher proportion of male with tertiary degrees.

The difference between the trend and constant scenario are quite minimal, especially for the two categories 'no schooling' and 'primary education' which is a reflection the long tradition of important investments in education as mentioned in the introduction. As a result, even if enrolments were maintained at current level observe in 2000, the working age population of Singapore would still be for $40 \%$ with some tertiary education and around $25-30 \%$ in Malaysia, the Philippines, and Thailand.

An interesting question is that of Asia's demographic bonus in the future. It is almost accepted that the effect of the rapid and early demographic transition created a demographic bonus during the last 30 years that together with high investment in education most Southeast Asian countries were able to translate into an economic window of opportunity using human capital more than physical capital to obtain high levels of economic growth. Considering the high levels of education and the dependency ratios shown in figure 2 one can predict more years for the Southeast Asian countries to benefit from this demographic and education constellation. Most countries will have declining total dependency ratios below $50 \%$ for the projected period that is the case of the Philippines, Vietnam, Malaysia, and Indonesia. In Singapore and to a lesser extent Thailand, the bonus will last for a shorter time, as dependency ratio will start to increase around 2015-2020 for both countries. This will be quite rapid for Singapore.

Figure 2. Total dependency ratios (ratio of the sum of the population aged 0-14 and that aged $65+$ to the population aged 15-64), 1970-2030

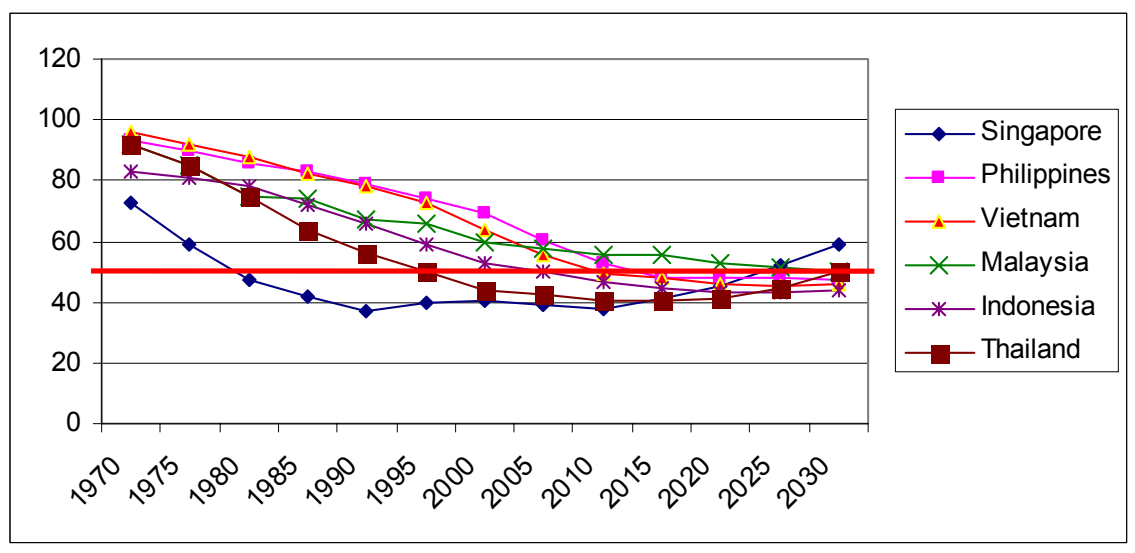


Table 12. Mean years of schooling of the population aged 20-64 during 1970-2030

\begin{tabular}{|c|c|c|c|c|c|c|c|c|c|}
\hline & & Indonesia & Malaysia & Philippines & Singapore & Thailand & Vietnam & China & India \\
\hline \multirow[t]{7}{*}{ Male } & 1970 & 5.4 & 6.2 & 7.2 & 5.0 & 6.0 & 5.3 & 5.7 & 4.2 \\
\hline & 1980 & 6.6 & 8.3 & 8.1 & 7.1 & 7.2 & 6.4 & 7.5 & 5.1 \\
\hline & 1990 & 7.9 & 10.1 & 8.7 & 8.6 & 8.0 & 7.0 & 8.7 & 6.0 \\
\hline & 2000 & 9.0 & 11.5 & 9.2 & 9.7 & 9.2 & 7.4 & 9.5 & 7.0 \\
\hline & 2010 & 9.7 & 12.7 & 9.5 & 10.2 & 9.4 & 7.9 & & \\
\hline & 2020 & 10.0 & 13.1 & 9.6 & 10.4 & 9.9 & 8.1 & & \\
\hline & 2030 & 10.3 & 13.4 & 9.8 & 10.6 & 10.4 & 8.3 & & \\
\hline \multirow[t]{7}{*}{ Females } & 1970 & 3.1 & 3.7 & 6.8 & 3.0 & 4.6 & 3.1 & 3.0 & 1.5 \\
\hline & 1980 & 4.5 & 6.1 & 7.8 & 5.3 & 6.1 & 4.5 & 4.9 & 2.1 \\
\hline & 1990 & 6.1 & 8.5 & 8.7 & 7.4 & 7.2 & 5.7 & 6.7 & 2.9 \\
\hline & 2000 & 7.9 & 10.6 & 9.4 & 8.9 & 8.7 & 6.5 & 8.0 & 4.0 \\
\hline & 2010 & 9.2 & 12.2 & 9.9 & 9.8 & 9.2 & 7.3 & & \\
\hline & 2020 & 9.6 & 12.8 & 10.1 & 10.2 & 9.8 & 7.6 & & \\
\hline & 2030 & 10.1 & 13.3 & 10.3 & 10.6 & 10.4 & 7.9 & & \\
\hline \multirow[t]{7}{*}{ Both } & 1970 & 4.3 & 4.9 & 7.0 & 4.1 & 5.3 & 4.2 & 4.4 & 2.9 \\
\hline & 1980 & 5.6 & 7.2 & 7.9 & 6.2 & 6.6 & 5.4 & 6.3 & 3.7 \\
\hline & 1990 & 7.0 & 9.3 & 8.7 & 8.0 & 7.6 & 6.3 & 7.7 & 4.5 \\
\hline & 2000 & 8.4 & 11.1 & 9.3 & 9.3 & 8.9 & 7.0 & 8.7 & 5.6 \\
\hline & 2010 & 9.4 & 12.4 & 9.7 & 10.0 & 9.3 & 7.6 & & \\
\hline & 2020 & 9.8 & 13.0 & 9.9 & 10.3 & 9.9 & 7.8 & & \\
\hline & 2030 & 10.2 & 13.4 & 10.1 & 10.6 & 10.4 & 8.1 & & \\
\hline
\end{tabular}




\section{Conclusions and Avenues for Future Research}

This paper on human capital in Southeast Asia has three main focuses: the first is to analyze the current situation regarding education in the six countries of choice, namely Indonesia, Malaysia, Philippines, Singapore, Thailand, and Vietnam. The second is the reconstruction and analysis of past levels of educational attainment for those countries above mentioned from 1970 to 2000 . The third focus is the projection of the levels of educational attainment from 2000 up to 2030.

Education is thought to be essential for Southeast Asia as it was and will continue to be the key element for protection against vulnerability to economic shock (such as the economic crisis of 1997-98) and for sustaining rapid economic growth.

The group of countries that were chosen are clearly determined in investing in education as can be seen from the levels of enrolment, the levels of educational attainment across cohorts, and average years of schooling for the population aged 20-64 in the past and at present. However, the pace of change was different between the countries. Singapore and Malaysia were definitely the front-runners of increases in the levels of educational attainment of the working age population in the last 30 years whereas Vietnam seems to be at the tail of the six countries, although it is benefiting in the last years from important investments in education. Thailand and the Philippines find themselves at an intermediate position between Vietnam on one hand and Malaysia and Singapore on the other hand. Indonesia is a country apart as some of its performance in terms of enrolments and investments are rather weak after a strong expansion in the 1970s after the oil boom.

Past investments in education of the region come out also very clearly from the projections of levels of educational attainment up to 2030 from both the trend and the constant scenario. According to the trend scenario, Singapore will remain the front runner in terms of education as the bulk of the working age population will have a tertiary education. Malaysia will also experience a rapid increase in its tertiary educated working age population but to a lesser extent than in Singapore. The Philippines based on the trend scenario will have a dichotomous society with still a large proportion with primary education and tertiary education. In Indonesia, the bulk of the working age population will shift from primary in 2000 to secondary in 2030. Recent rapid increases in enrolment in Thailand will pay off by 2030 as it will increase the share of the working age population both with a secondary and tertiary education. The trend scenario does not allow Vietnam to catch up by 2030 but this may hide some rapid changes that could occur if economic development is particularly beneficial. These developments in the levels of educational attainment of the working age population will be extremely favourable as during most of the next 30 years, the population of the six countries will benefit from decreasing dependency ratio that gives all countries a demographic bonus. However the 2020-30s will mark the end of that bonus period. In this context human capital will be essential. 
This work points out several avenues of research. The first one would be to change the scale of the research and not only to look at the national level but also at the sub-regional level and have an in-depth perspective of the coastal areas' working age and level of educational attainment to evaluate the vulnerability of the population and the imbalances in the population.

The second avenue is to not only look at number of population but also at the quality and curriculum which should always be kept in mind when projecting the future educational levels of the population. For instance, input in education can be measured by the availability of teachers in relation to the number of students. The pupil-teacher ratios as well as the proportion of trained teachers in the country are good indicators of the quality of education. According to UNESCO (2004), the Philippines have the highest ratios at all levels of education, comparable to those of India. Indonesia has low ratios, but it hides the reality that a large proportion of the teachers, especially at secondary levels are not trained (about $47 \%$ in 2000-01 according to the UNESCO). Malaysia, that is one the countries spending the most on education, has very few students per teacher at all levels of education. 


\section{References}

AWANG, H (2004) 'Human capital and technology development in Malaysia', International Education Journal, vol. 5 no. 2, pp. 239-246.

BAPPENAS (2006) Overview of the Indonesia's Medium Term Development Plan 2004 2009. Available online at: http://www.bappenas.gov.id/Berita dan Siaran Pers/Ekonomi/Overview of the Indonesia's Medium-Term Development Plan 2004 $2009[7 / 10 / 2006]$

BEHRMAN, J.R., A.B. Deolalikar \& L-Y Soon (2002) 'Promoting effective schooling through education decentralization in Bangladesh, Indonesia, and Philippines', Economics and Research Department ERD Working Paper Series, no. 23, Asian Development Bank, Manila.

BJORK, C. (2004) 'Decentralisation in education, institutional culture and teacher autonomy in Indonesia', International Review of Education, vol. 50 no. 3-4, pp. 245-262.

BOOTH, A. (2000) 'Poverty and inequality in the Soeharto era: An assessment', Bulletin of Indonesian Economic Studies, vol. 36, no. 1, pp. 73-104.

BPS STATISTICS INDONESIA, BAPPENAS \& UNITED NATIONS DEVELOPMENT PROGRAMME (2004) National Human development Report 2004, The Economics of democracy: Financing Human Development in Indonesia, UNDP, Jakarta.

DOUANGNGEUNE, B., Y. HAYAMI \& Y. GODO (2005) 'Education and natural resources in economic development: Thailand compared with Japan and Korea', Journal of Asian Economics, no. 16, pp. 179-204.

FAN, S., S. JITSUCHON \& N. METHAKUNNAVUT (2004) 'The importance of public investment for reducing rural poverty in middle-income countries: The case of Thailand, SGD Discussion Paper, no. 7, Development Strategy and Governance Division, International Food Policy Research Institute, Washington, DC.

GLEWWE, P. \& H.A. PATRINOS (1998) 'The role of the private sector in education in Vietnam. evidence from the Vietnam living standards survey', LSMS Working Paper, no. 132, The World Bank, Washington, DC.

GOUJON, A (1997) 'Population and education prospects in the Western Mediterranean region: Jordan, Lebanon, Syria, the West Bank and the Gaza Strip', IIASA Interim Report IR-97-046, International Institute for Applied Systems Analysis, Laxenburg, Austria.

GOUJON, A. \& K. MCNAY (2003) 'Projecting the educational composition of the population of India: Selected state-level perspectives', Applied Population and Policy, vol.1, no. 1, pp. 25-35.

GOUJON, A., I. KOHLER \& W. LUTZ (2000) Future population and education trends: Scenarios to 2030 by socioecological region, in Lutz, W., L. Prieto \& W. Sanderson (eds.) Population, development, and environment on the Yucatan Peninsula: From Ancient Maya to 2030, IIASA Research Report RR-00-14, International Institute for Applied Systems Analysis, Laxenburg, Austria, pp. 141-173.

JATRANA, S. \& Y. MUI TENG (2001) Singapore Country Report. Unpublished 
JEONG, H (2005) 'Assessment of relationship between growth and inequality: micro evidence from Thailand', IEPR Working Paper, no. 05.20, Institute of Economic Policy Research, University of Southern California.

KRISTIANSEN, S. \& PRATIKNO (2006) 'Decentralising education in Indonesia', International Journal of Educational Development, vol. 26, no.5, pp. 513-531.

LANJOUW, P., M. PRADHAN, F. SAADAH, H. SAYED \& R. SPARROW (2001) 'Poverty, education and health in Indonesia: Who benefits from public spending?', Policy Research Working Paper Series no. 2739, The World Bank, Washington DC.

LUTZ, W. (ed.) (1994) Population, Development, Environment: Understanding their Interactions in Mauritius, Springer Verlag, Heidelberg.

LUTZ, W. \& A. GOUJON (2001) 'The world's changing human capital stock: Multi-state population projections by educational attainment', Population and Development Review, no. 272, pp 323-339.

LUTZ, W., A. GOUJON \& A. WILS (Forthcoming) Forecasting human capital using demographic multi-state methods by age, sex, and education to show the long-term effects of investments in education. World Bank Working Paper.

MASON, T.C., R.F. ARNOVE \& M. SUTTON (2001) 'Credits, curriculum, and control in higher education: Cross-national perspectives’, Higher Education, no. 42, pp 107-137.

MCNICOLL, G. (2006) 'Policy Lessons of the East Asian Demographic Transition', Population and Development Review, vol. 32, no. 1, pp. 1-25.

MUKHOPADHAYA, P. (2001a) 'Changes in social welfare in Singapore - 1982-1999. Department of Economics Working Paper, no. 0120, National University of Singapore, Singapore.

MUKHOPADHAYA, P. (2001b) 'Changing labor-force gender composition and male/female income diversity in Singapore', Journal of Asian Economics, vol. 12 (2001), pp. 547568.

NARANONG, V (1998) 'Gender, credit constraints, and education in rural Thailand', Economic growth Center Working Papers, no. 792., Economic Growth Center, Yale University.

SJÖHOLM, F (2002) 'Educational reforms and challenges in Southeast Asia' The European Institute of Japanese Studies Working Paper, no. 152, Stockholm School of Economics, Stockholm.

THOMAS, D., K. BEEGLE, E. FRANKENBERG, B. SIKOKI, J. STRAUSS \& G. TERUEL (2004) 'Education in a crisis', Journal of Development Economics, vol. 74, no. 1, pp. 53-85.

UNDP MALAYSIA (2006) Malaysia International Trade, Growth, Poverty and Human Reduction Development, United Nations Development Programme, Kuala Lumpur.

UNESCO (2004) Database available online at: http://stats.uis.unesco.org/ReportFolders/reportfolders.aspx

UNITED NATIONS (1995) Population and development: Programme of Action adopted at the International Conference on Population and Development, Cairo 5-13 September 1994, Volume 1, United Nations/UNFPA, New York, NY.

UNITED NATIONS (2004) World population prospects: The 2004 revision, United Nations, New York, NY. 
WELCH, A.R (2006) 'Blurred vision? Public and private higher education in Indonesia', Higher Education, online first.

WILS, A (1996) 'PDE Cape Verde: A systems study of population development and environment', IIASA Working Paper, WP.96.09, International Institute for Applied Systems Analysis, Laxenburg, Austria.

WORLD BANK (1997) A World Bank Country Study, Vietnam: Education Financing, The World Bank, Washington DC.

WORLD BANK (2006) Education for All - Fast-track Initiative. Available at: http://www1.worldbank.org/education/efafti/ [16/10/06\}

YOUSIF, H.M., A. GOUJON \& W. LUTZ (1996) 'Future population and education trends in the countries of North Africa', Research Report, RR-96-11, International Institute for Applied Systems Analysis, Laxenburg, Austria. 
Annex: Population Pyramids of working-age population (20-64) by levels of educational attainment 
1. Indonesia

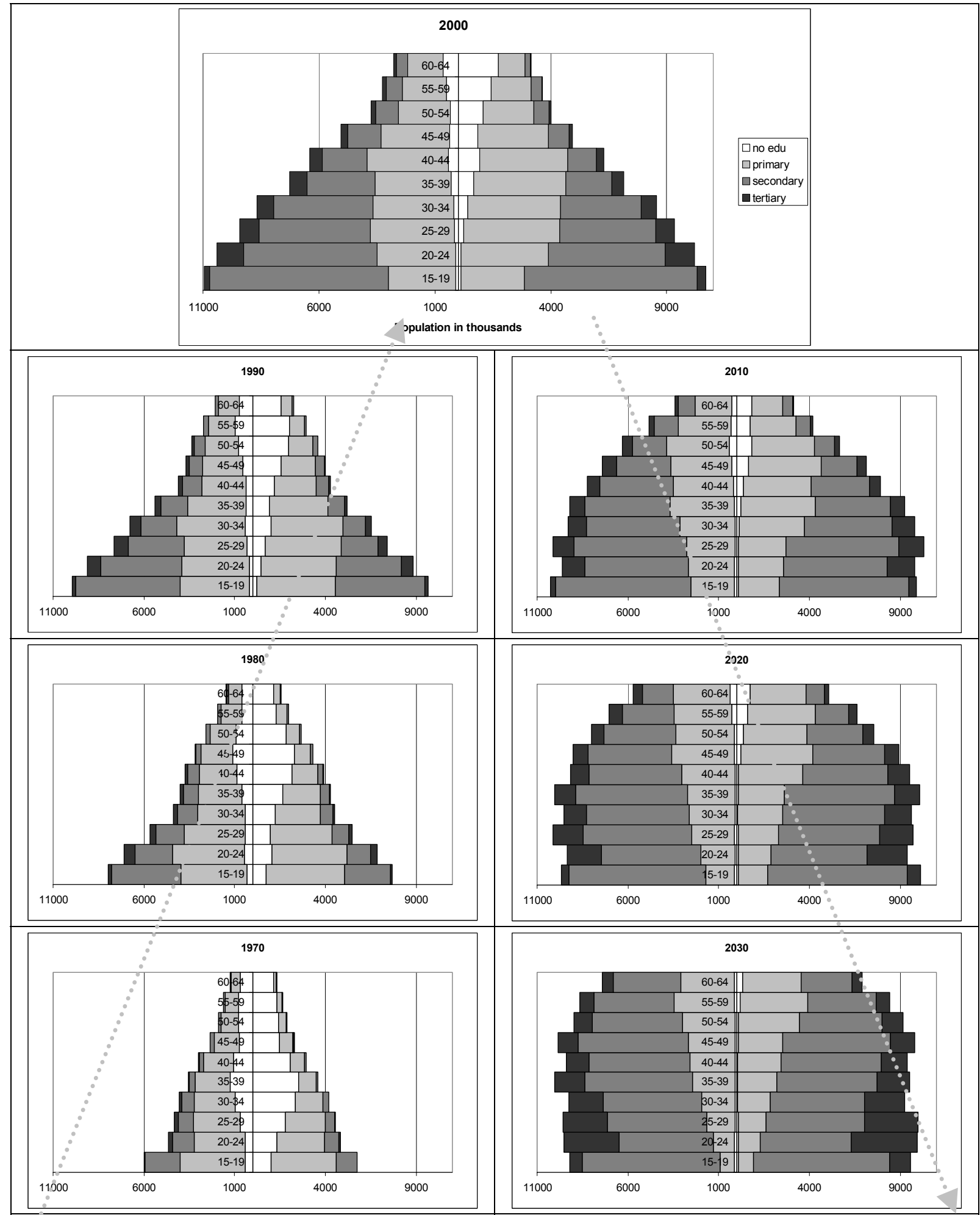


2. Malaysia

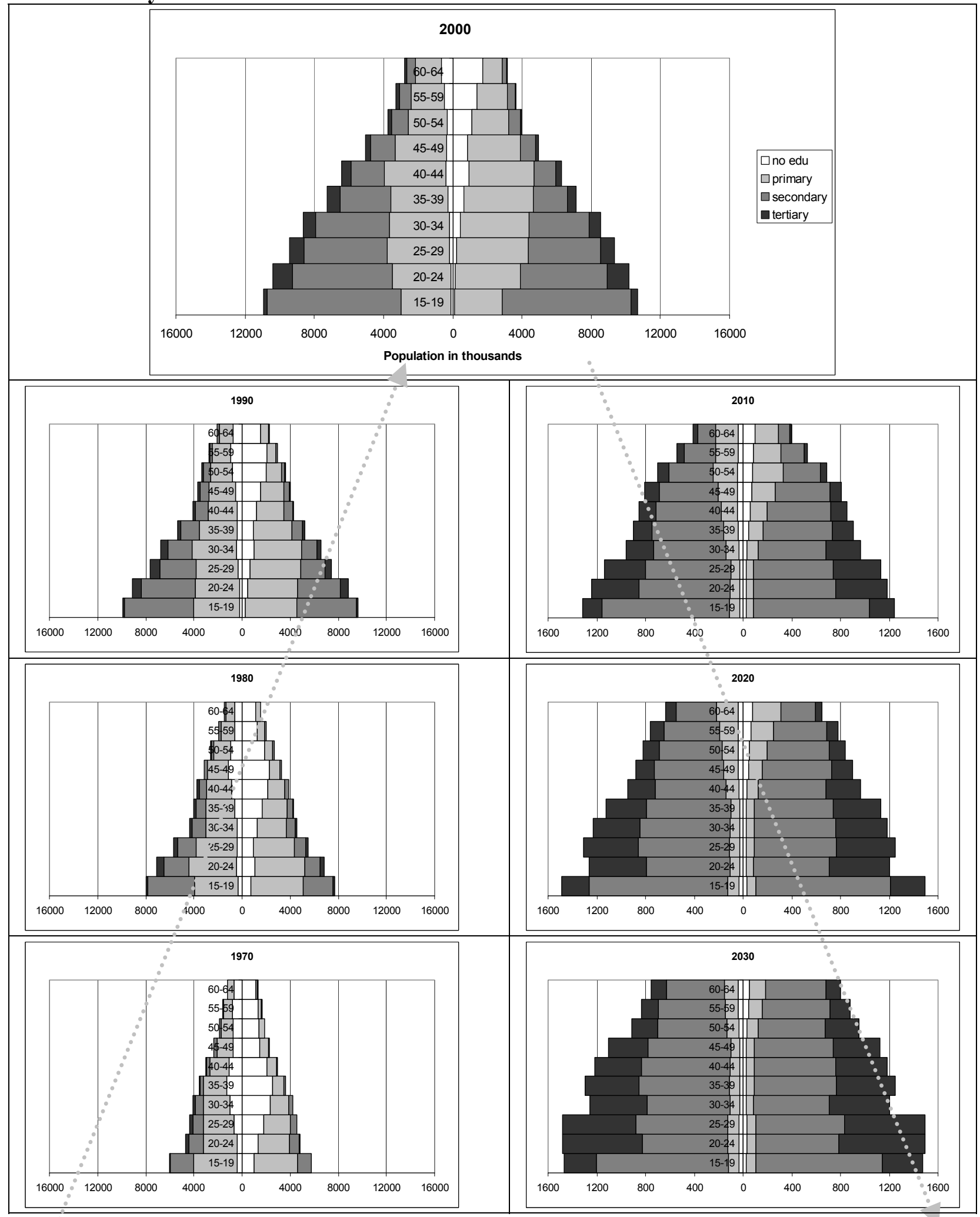




\section{Philippines}

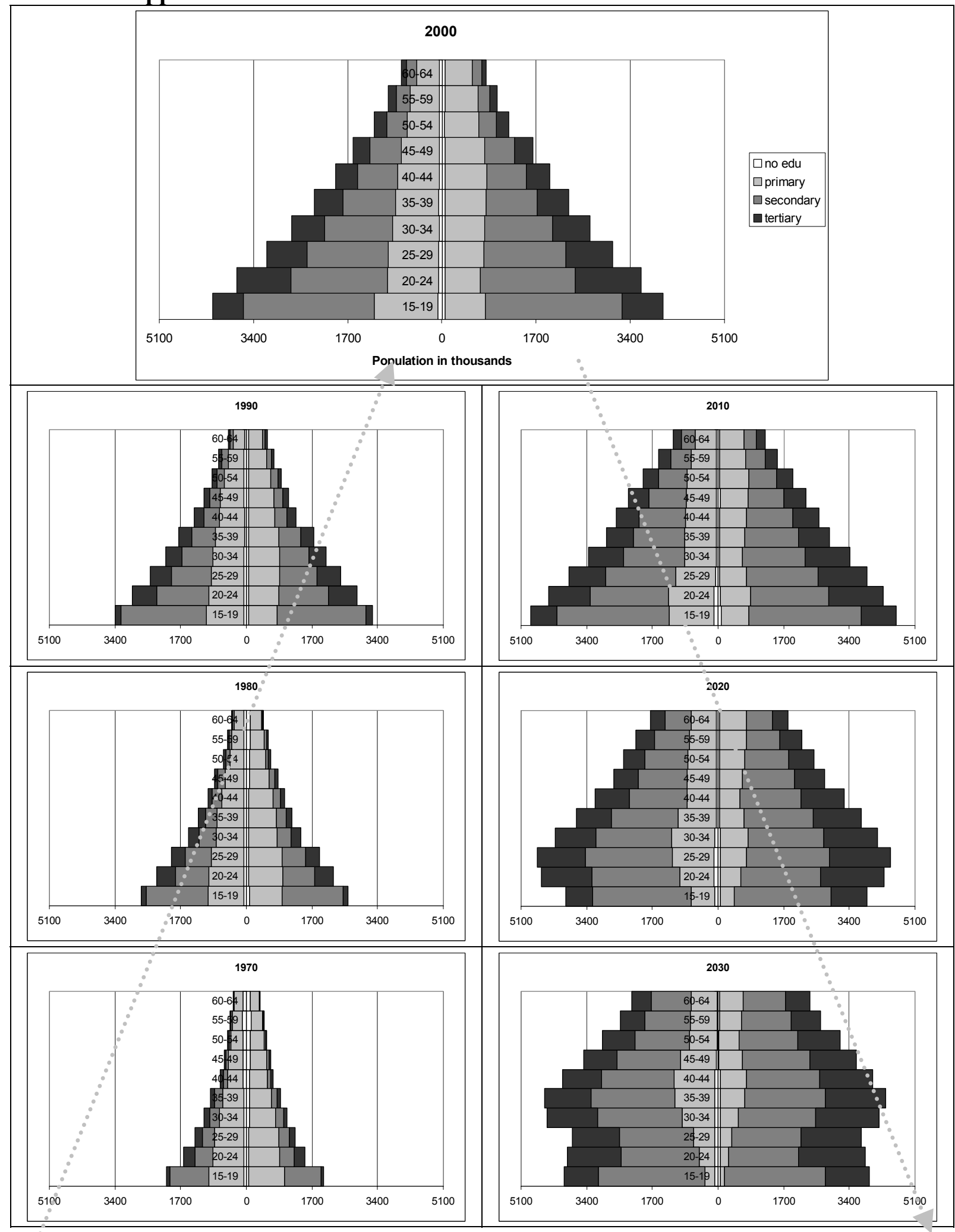


4. Singapore

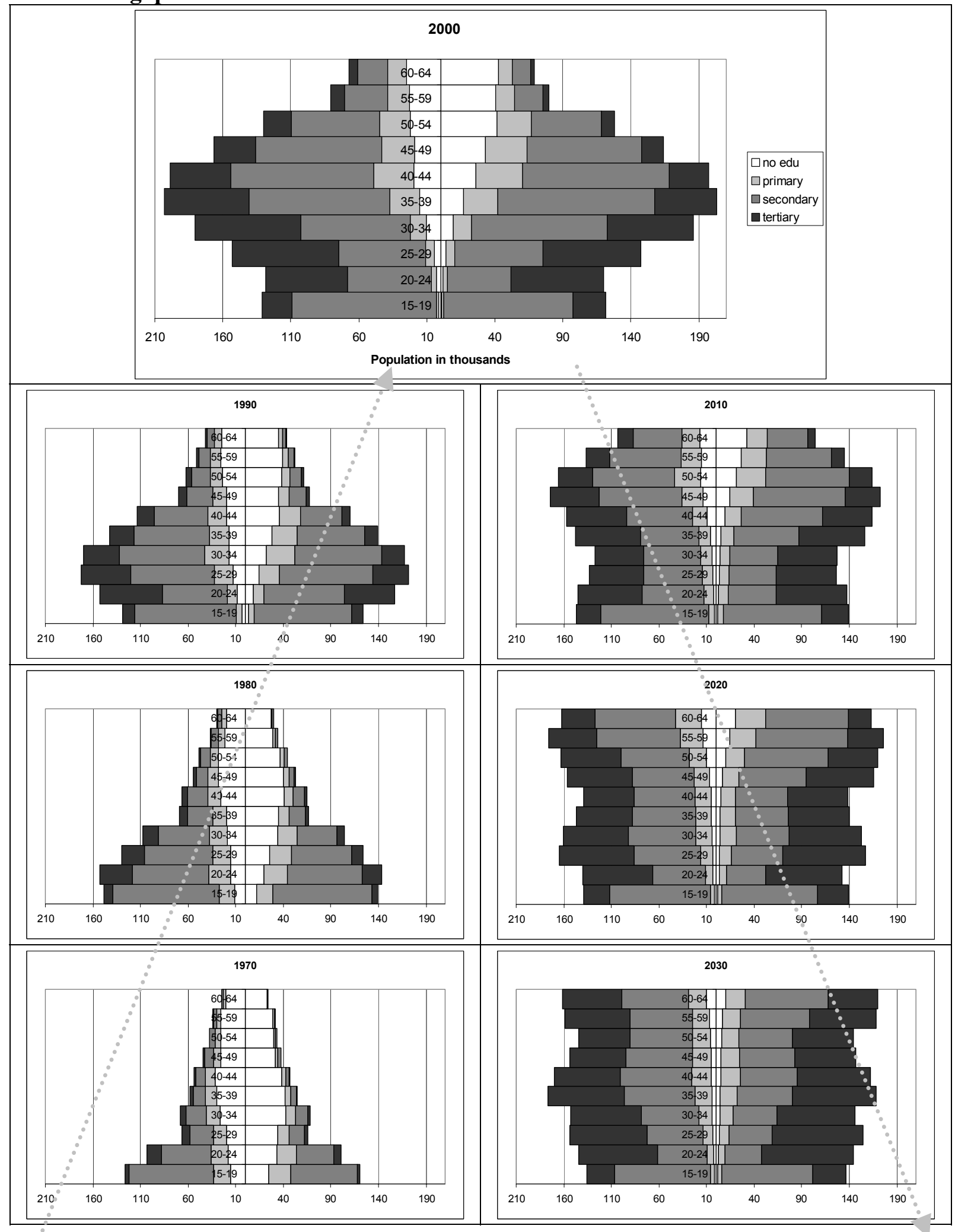


5. Thailand

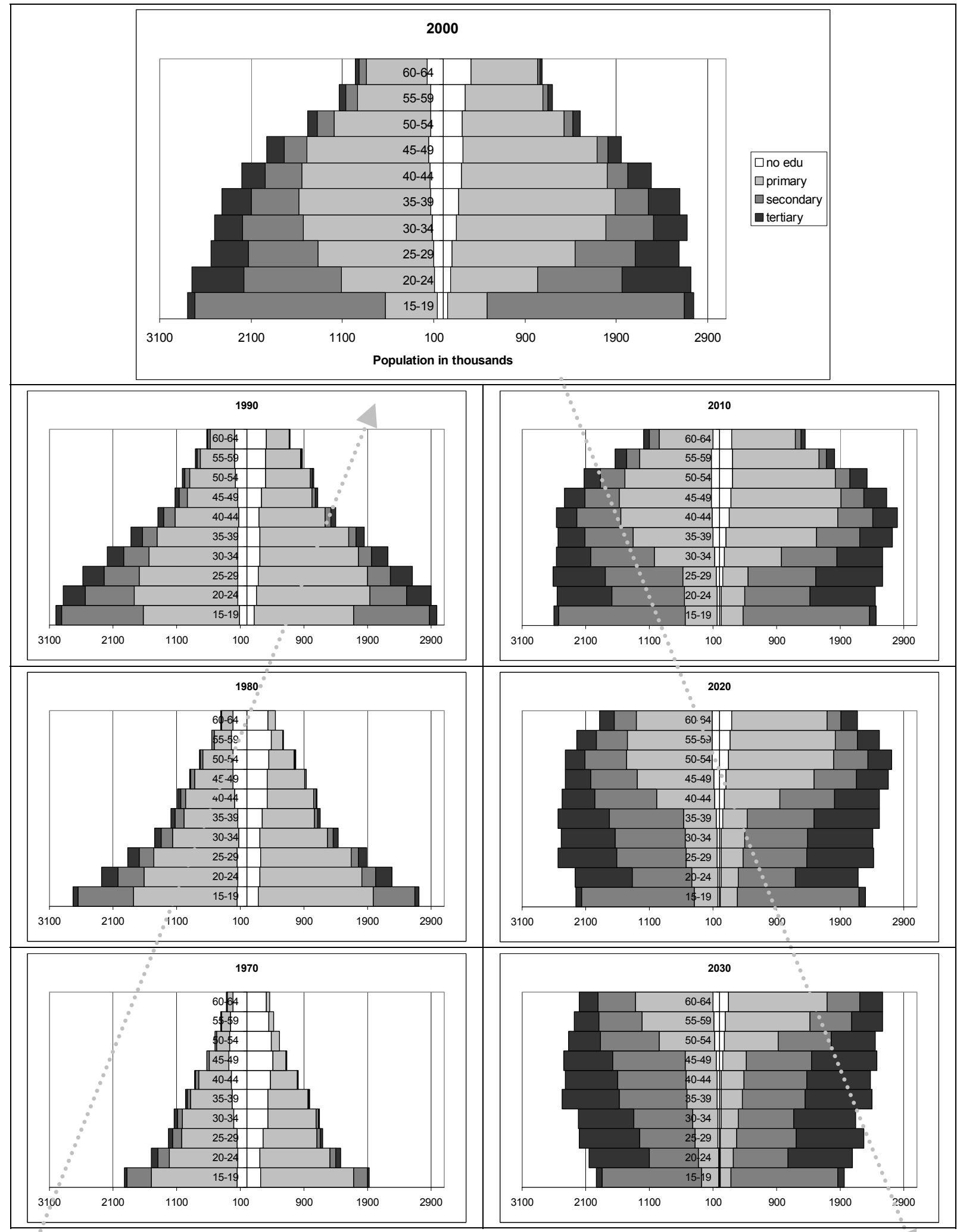


6. Vietnam

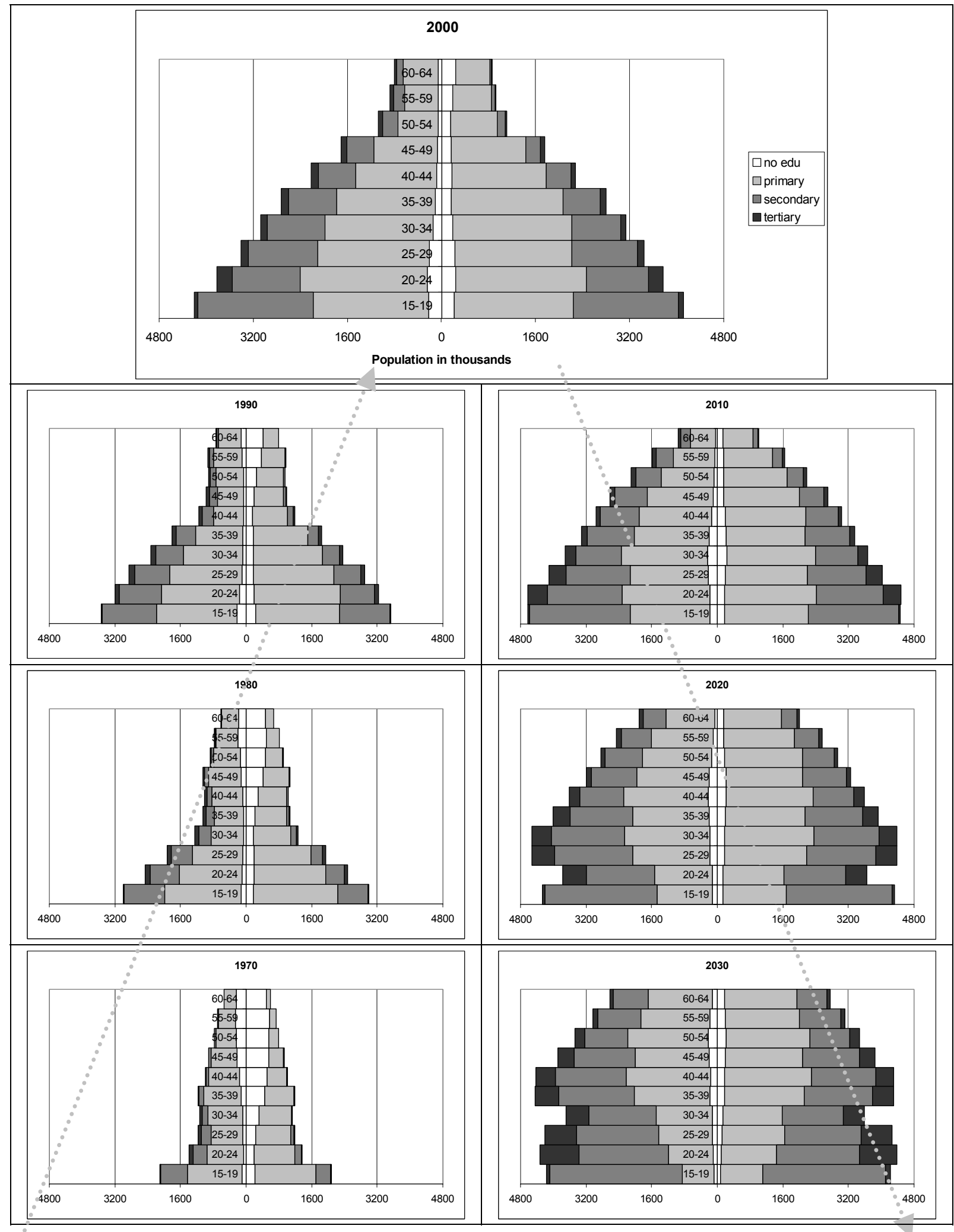




\section{VIENNA INSTITUTE OF DEMOGRAPHY}

\section{Working Papers}

Lyngstad, Torkild H., Does Community Context have Important Bearings on the Divorce Rate? VID Working Paper 06/2006.

Winkler-Dworak, Maria, The Low Mortality of a Learned Society, VID Working Paper 05/2006.

Kim, Jungho and Alexia Prskawetz, External Shocks, Household Consumption and Fertility in Indonesia, VID Working Paper 04/2006.

Schwarz, Franz, Behavioral Explanation for Educational Health and Mortality Differentials in Austria, VID Working Paper 03/2006.

Schwarz, Franz, The Contributions of Diseases to Increasing Educational Mortality Differential in Austria, VID Working Paper 02/2006.

Goujon, Anne, Vegard Skirbekk, Katrin Fliegenschnee and Pawel Strzelecki, New Times, Old Beliefs: Projecting the Future Size of Religions in Austria, VID Working Paper 01/2006.

Ediev, Dalkhat M., Extension of Fisher's Classical Result on Exponential Dynamics of the Reproductive Value to a Wide Class of Populations, VID Working Paper $10 / 2005$.

Ediev, Dalkhat M., Long-Term Effects of Childbearing Postponement, VID Working Paper 09/2005.

Philipov, Dimiter, Zsolt Spéder, and Francesco C. Billari, Now or Later? Fertility Intentions in Bulgaria and Hungary and the Impact of Anomie and Social Capital, VID Working Paper 08/2005.

Schwarz, Franz, Widening Educational Differentials in Mortality: Analysis for Austria with International Comparisons, VID Working Paper 07/2005.

Kim, Jungho, Henriette Engelhardt, Alexia Prskawetz, and Arnstein Aassve. Does Fertility Decrease the Welfare of Households? An Analysis of Poverty Dynamics and Fertility in Indonesia, VID Working Paper 06/2005.

Kim, Jungho. Women's Education in the Fertility Transition: The Reversal of the Relationship Between Women's Education and Birth Spacing in Indonesia, VID Working Paper 05/2005.

The Vienna Institute of Demography Working Paper Series receives only limited review. Views or opinions expressed herein are entirely those of the authors. 